Chapter 8

\title{
Assessment of Historical Heavy Metal Pollution of Land in the Proximity of Industrial Area of Targoviste, Romania
}

\author{
Carmen Cristina Elekes \\ Additional information is available at the end of the chapter \\ http://dx.doi.org/10.5772/58304
}

\section{Introduction}

Contamination of soil and water with organic and inorganic pollutants is a subject of interest to European policy, looking for new ways of preventing pollution and remediating polluted sites. Source and type of contamination influences the nature of pollution and methods of remediation. Thus, accidental discharge can be isolated more easily from a small area of soil, while the contamination of water is more difficult to control. Deposition of particulate matter can contaminate wide surfaces with low concentrations of contaminants. However, particulate matter is the main source of contamination of soils with heavy metals.

Many international researches have studied the concentrations of metals in soil, in correlation with texture, structure and $\mathrm{pH}$ of soil. In order to reduce the concentration of heavy metal to a level allowing development of all crop plants under a secure intake level of heavy metals, pollution mitigation measures should be applied on those soils. Depending on land use, the legislation of each country establishes the normal and maximal limits of heavy metals in soil.

The development of metallurgical activities in an irresponsible manner and without taking into account the environmental damage, lead to a historical accumulation of heavy metals in soil. The concentration of heavy metals in soil varies significantly depending on the type of soil and geographic region. This indicates that the parental material, climatic conditions and human activities have a predominant impact on the chemical forms (speciation) and on the mobility of metals in soil. In addition to the methods of prevention and mitigation of pollutants emissions, there are a number of methods of remediation, based on soil stripping and replacement or methods of bioremediation. 
Across Europe, an extensive study was conducted concerning the concentration of heavy metals in soil [1], involving the collaboration of several organizations: EuroGeo Survey, Geological Survey of Finland (GTK) and the Forum of European Geological Survey Directors (FOREGS). The project was conducted between 1996 and 2003, but unfortunately did not cover the Romanian territory. At the end of the project were drawn distribution maps of all metals in soils and sediments found along rivers and a Geochemical Atlas of Europe was designed.

Another significant study is Alina Kabata-Pendias book "Trace Elements in Soils and Plants" published so far in four editions [2]. This book provides a concise but comprehensive overview of the biogeochemistry of trace elements found in the soil-plant system. Includes over 400 references to recent studies that have been conducted to determine the metal content of the soil-plant system and highlights the significance of anthropogenic factors leading to the change of state elements in soil and plants. Subjects are bioindicators behaviour in the environment, soil remediation, and hyperaccumulation and hyperextraction of heavy metals from soil.

Organizations such as the Food and Agriculture Organization (FAO) and World Health Organization (WHO) have established very comprehensive reports related to the concentration of metals in food and doses considered daily necessary, maximum intake for different age groups, maximum limits in food and soils (Table 1). In Romania, the reference values for trace metals in soils are governed by Order 756 / 3rd of November 1997 [3]. It regulates normal values, alert thresholds and action levels for different trace elements by use of soils.

\begin{tabular}{ccccccc}
\hline \multirow{2}{*}{$\begin{array}{c}\text { Heavy } \\
\text { metal }\end{array}$} & \multicolumn{3}{c}{ Canadian Standard } & \multicolumn{3}{c}{ Dutch standard } \\
\cline { 2 - 7 } & Arable land & Inhabited area & Industrial area & Arable land & Inhabited area & Industrial area \\
\hline $\mathrm{Cu}$ & 150 & 100 & 150 & 36 & 100 & 500 \\
$\mathrm{Zn}$ & 600 & 500 & 600 & 140 & 500 & 3000 \\
$\mathrm{Cd}$ & 3 & 5 & 3 & 0,8 & 5 & 20 \\
$\mathrm{~Pb}$ & 375 & 500 & 375 & 85 & 150 & 600 \\
\hline
\end{tabular}

Table 1 Maximum limits of heavy metals in soil, according with Canadian and Dutch standards (ppm) [4]

The present study completes FOREGS project and aims to establish the concentrations of heavy metals in an industrial area, near the city of Targoviste. Depending on the climatic characteristics, on topography and on pollution rose, we have established representative points of soil sampling for the area. Samples were collected from both the surface of soil to determine the horizontal distribution of heavy metals in the industrial area, as well as on profile $(0-40 \mathrm{~cm})$ to determine the vertical distribution of the metals and to assess the extent of historical pollution.

\section{Heavy metals occurrence in soil and potential impact on life quality}

The problem of soil contamination with heavy metals, fuel and other toxic materials is a reality worldwide. Following the accidents which occurred with discharges of toxic materials on the 
ground, the affected area increased by infiltration of substances into groundwater. The groundwater is carrying the pollutants to residential areas, endangering the health of residents.

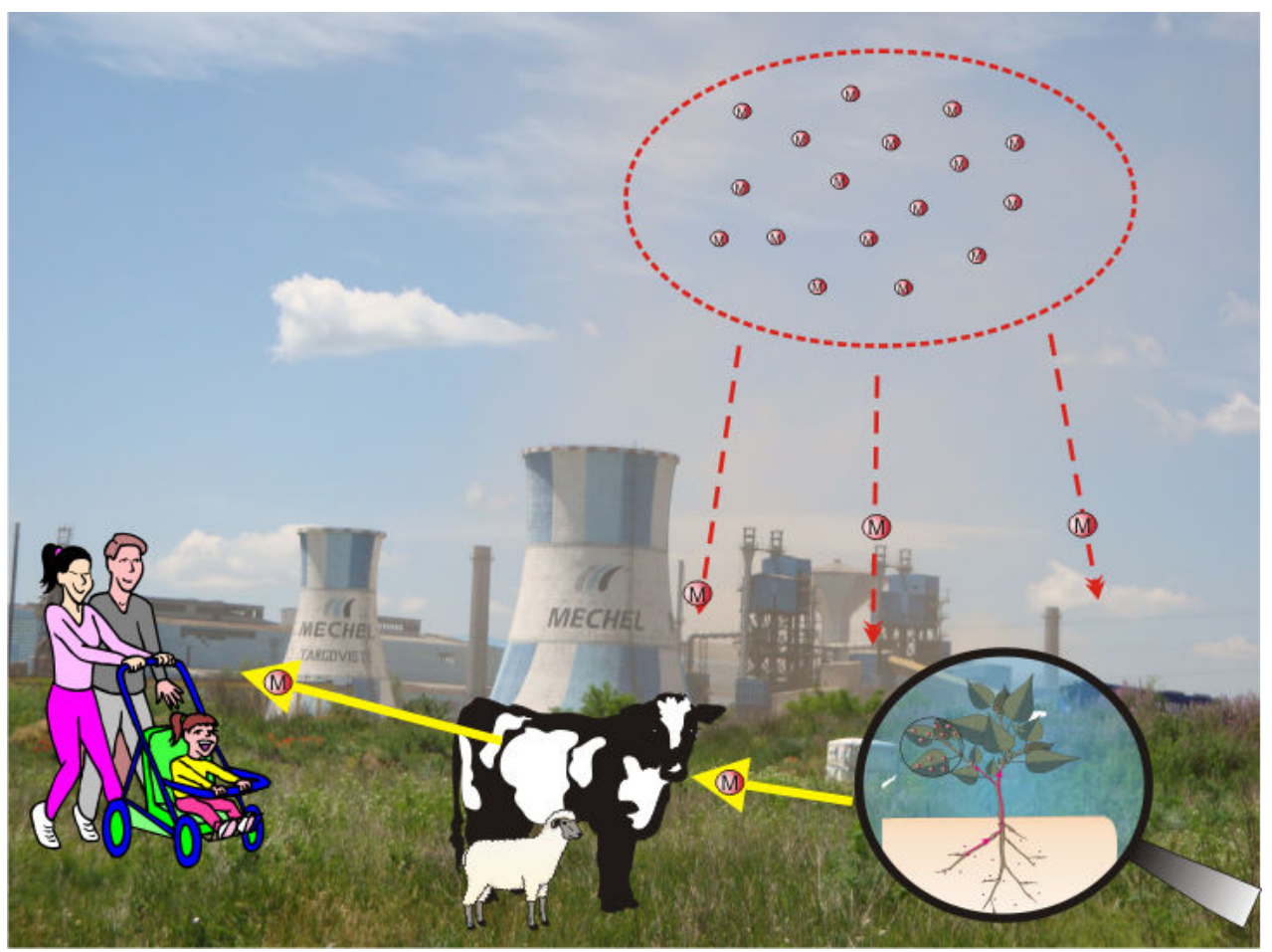

Figure 1. Transfer of metallic particulate to human body

Heavy metals are natural components, which occurred in high concentrations under natural conditions. In the twentieth century, metalliferous uploading of air, water, soil and therefore of plants and the human body, has become an important concern of international researchers. Heavy metals are considered a risk for living organisms because they tend to bioaccumulate. Bioaccumulation is an increase of concentration of a chemical in living organisms, as compared to the concentration of the element in the environment. Compounds are accumulated in living organisms by uptake from environment and storage at a higher rate than that of metabolism or excretion.

Emissions from metallurgical plants are transported by air masses and then deposited on the ground, leading to an increase of metal concentration in the upper layer of soil. Plants, perennial grasses especially have a high storage capacity of such metals in their shoots. The plants loaded with large amounts of heavy metals are consumed by animals that are grazing of this land (Figure 1). 
Metal concentration in soil varies significantly depending on the soil type, but also by region $[5,6]$. This indicates that the parent material and climatic conditions have a predominant impact on the chemical state of metals in soil. Kabata-Pendias and Krakowiak [7] set a factor of soil parameters (RDI - Relative explanation index) based on the calculation of correlation coefficients matrix for metals and some soil parameters: $\mathrm{pH}$, clay content, cation exchange capacity, substance the organic content of the soil and iron. For approx. 1000 samples, the strongest positive linear correlation was obtained for metals and fine fraction of the soil. This relationship varies for the metals studied and is well illustrated by the content of heavy metals in soil which increases with increasing clay content. The highest value of the RDI when correlated with clay content $(60-75 \%)$ was calculated on $\mathrm{Zn}, \mathrm{Fe}, \mathrm{Ni}$ and $\mathrm{Cr}$, while the lower value (10-30\%) was calculated for $\mathrm{Cd}, \mathrm{Pb}, \mathrm{Cu}$, and $\mathrm{Mn}$ (Figure 2 ).
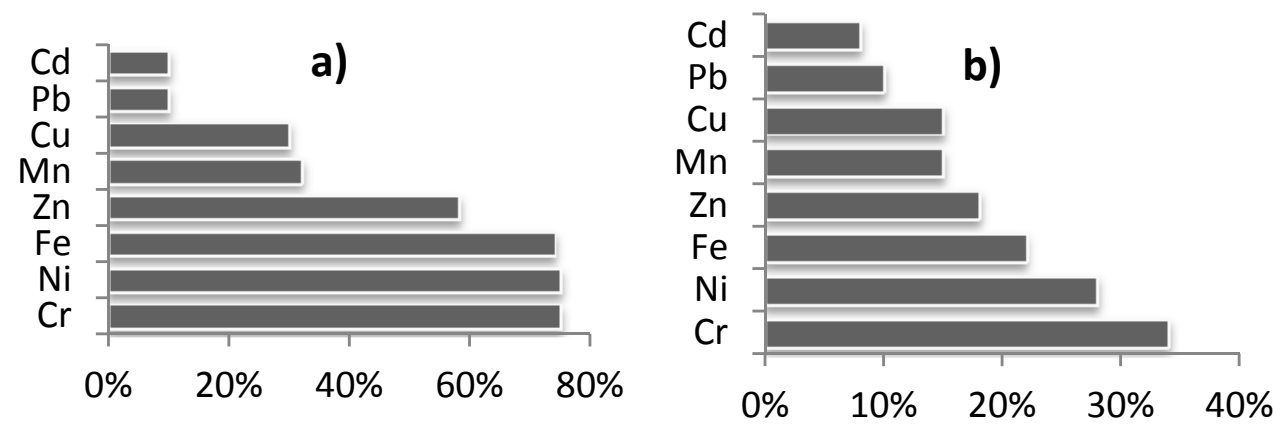

Figure 2. Relative explanation index (RDI), of statistically significant relationship at $99 \%$ confidence level, between heavy metals in soil and clay content $<0.02 \mathrm{~mm}$ (a) and cation exchange capacity in soil (b) [2]

Copper $(\mathrm{Cu})$ is an important element for all life forms, but can be toxic in high concentrations. The average $\mathrm{Cu}$ content in the lithosphere is $70 \mathrm{ppm}$. In natural soils, the average concentration is 2-40 ppm. As described for $\mathrm{Ni}, \mathrm{Cu}$ has no similarities with any other metal regarding his chemical behaviour in soil. Significant quantities of $\mathrm{Cu}$ in the soil are connected in the minerals, therefore, this metal is supplied only by a very slow decay processes. Cu may occur in the form of readily soluble salts (copper nitrate, copper sulphate), and as an oxide and hydroxide. It binds to organic matter, ferric oxide and $\mathrm{Al}$. Intake of $\mathrm{Cu}$ in plants can be increased by low $\mathrm{pH}$ and organic fertilizers. $\mathrm{Cu}$ concentration can increase significantly under the effect of anthropogenic activities (non-ferrous metal processing, the use of substances for plant protection). In humans, the contamination has not yet been notified by the dietary intake of $\mathrm{Cu}$ in the body, but its high concentration may cause liver damage.

Zinc $(\mathrm{Zn})$ is widespread in nature and the average content of $\mathrm{Zn}$ in the lithosphere is about 80 ppm. Unpolluted soil contains an average of 15-100 ppm of Zn. Zinc binds to organic matter and ferric and $\mathrm{Mn}$ oxides. It occurs in large amounts in the layers of the clay minerals. Under natural conditions, in A horizon of soil from wet areas, with slightly acid $\mathrm{pH}$, more than half of the $\mathrm{Zn}$ is bound to organic material [4]. Because of the extensive use of $\mathrm{Zn}$ in industry, the $\mathrm{Zn}$ content in soil surrounding the industrial areas can reach even $5000 \mathrm{ppm}$ [2]. The effect of 
$\mathrm{Zn}$ is particularly harmful because its accumulation leads to accumulation of other heavy metals, such as $\mathrm{Pb}, \mathrm{Cu}$ and cadmium (Cd). Concomitantly, in the lime-rich soils, the plants show $\mathrm{Zn}$ deficiency symptoms. Also, $\mathrm{Cd}$ is strongly chemical bond to the $\mathrm{Zn}$, as the proportion $\mathrm{Zn} / \mathrm{Cd}$ in soil is constant. The availability to plants can be influenced by the concentration of cadmium in soil, $\mathrm{pH}$ conditions, temperature, amount of organic matter, and presence of other metals. Cadmium is irreversibly bound by ferric and manganese oxides in soil, and by clay minerals that influence the $\mathrm{Cd}$ mobility.

Lead $(\mathrm{Pb})$ in soil is largely associated with colloidal organic matter, which results in a high proportion of $\mathrm{Pb}$ accumulated in the top $5-15 \mathrm{~cm}$ of contaminated soils. The $\mathrm{Pb}$ concentration decreases with depth in a soil profile [2]. In the geosphere, the average $\mathrm{Pb}$ concentration is about $16 \mathrm{ppm}$. The increasing of $\mathrm{Pb}$ concentration may be caused by the accumulation of fuel combustion residues from the transportation, by application of sewage sludge and by the use of some pesticides in gardens or orchards. Increasing soil $\mathrm{pH}$ may decrease the absorption of $\mathrm{Pb}$ in soil. Plants are able to accumulate significant amounts of $\mathrm{Pb}(300-400 \mathrm{ppm})$ in pollution conditions without noticeable symptoms [2]. High concentration of $\mathrm{Pb}$ particularly affects the neurovegetative functions, hampers blood and cause chronic emphysema in humans.

Tin (Sn) concentrations in soil are generally low, with values of $2-3 \mathrm{mg} / \mathrm{kg}$ in unpolluted areas and can reach $200-1000 \mathrm{mg} / \mathrm{kg}$ in areas of high tin deposits [8] or in areas influenced by anthropogenic activities including smelters of ferrous and non-ferrous metals and coal-fired power plant [9].

Cobalt (Co) is widely distributed in rocks and soils and always occurs in nature in association with nickel and usually with arsenic [10]. The common Co minerals are smaltite $\left(\mathrm{CoAs}_{2}\right)$ and cobaltite (CoAsS) and the most important sources of cobalt are residues from the smelting of arsenical ores of nickel, cobalt and lead [10]. Cobalt in environment may represent a hazard to human health and is considered a metal with marked allergenic potential.

Chromium ( $\mathrm{Cr}$ ) is used in alloying metals, in the industry of paints, cement, paper, rubber and other materials. Exposure to low concentrations of $\mathrm{Cr}$ produce skin irritation and ulceration, and long-term exposure can cause kidney and liver diseases, and diseases of the circulatory system and nervous tissue. Chromium accumulates especially in aquatic fish and the consumption increases the risk of a high intake of this metal.

Nickel (Ni) is necessary in small quantities in the human body to produce red blood cells [4], but greater amounts $(>1.0 \mathrm{mg} / \mathrm{d})$ may become toxic. Short-term exposure to Ni does not cause health problems, but over a long period leads to weight loss, heart and liver diseases, and skin irritation. Nickel can accumulate in aquatic organisms, but its presence increases for higher levels on the food chain.

Manganese $(\mathrm{Mn})$ is a metal naturally ubiquitous in the environment, found in many types of rocks and soil, essential for normal physiologic functioning in humans and animal. Exposure to low levels of $\mathrm{Mn}$ is considered to be nutritional for humans. Long-term exposure to high levels of Mn by inhalation in humans may result in central nervous system effects. The metallic $\mathrm{Mn}$ is used in steel production to improve hardness, stiffness and strength. Mn is also used in 
carbon steel, stainless steel and high-temperature steel, along with cast iron and superalloys [11]. The average Mn levels in soil range from 40 to 900 ppm [11].

Molybdenum (Mo) is a valuable alloying agent which contributes to the hardness and toughness of quenched and tempered steels. Mo also improves the strength of steel at high temperature. In the environment, Mo differs from the other micronutrients in soils because it is less soluble in acid and more soluble in alkaline soils. Mo availability to plants is sensitive to $\mathrm{pH}$ and drainage conditions. Some plants can have up to $500 \mathrm{ppm}$ of the metal when they grow on alkaline soils [12].

\subsection{Heavy metal pollution of soil}

The presence of heavy metals in natural and contaminated soils shows a great variability in both the horizontal and vertical dimensions [2]. Chemical pollution of soils in Romania is affecting approx. 0.9 million ha of soil, of which 0.2 million ha are affected by excessive pollution. Adverse effects are particularly strong to pollution by heavy metals $(\mathrm{Cu}, \mathrm{Pb}, \mathrm{Zn}, \mathrm{Cd})$ and sulphur dioxide, identified especially in Baia Mare, Zlatna and Copsa Mica. Although in last years a number of industrial units have been closed and others have reduced activity, the soil pollution is quite high in some areas: Targu Mures, Turnu Magurele, Tulcea and Slatina. Oil pollution and salt water from oil wells and transport affects approximately 50, 000 ha. Soil damaged by excavation comprises 15,000 ha and constitutes the most serious form of damage to soil, encountered in the mining industry, for example in the mining basin of Oltenia. Suitability of land affected by this type of pollution decreased by 1-3 classes, and some of these areas has become unproductive. Soil cover with solid waste and residues caused sealing of approximately 18000 ha of farmland and meadows [13]. Direct economic damage on agricultural production due to these restrictions is estimated by reducing it by about $20 \%$ per year.

The study of Lăcătuşu and Ghelase [14] aimed to assess the abundance of anthropogenic heavy metals in soils at various distances from Romfosfochim SA Valea Călugărească. The researchers compared the specific data of metal concentrations in polluted soils with those of similar soils, not subject to pollution effects. The results showed a decrease in the percentage of geogenic abundance with proximity to the source of pollution, although the concentrations of $\mathrm{Cu}, \mathrm{Pb}, \mathrm{Zn}$ and $\mathrm{Cd}$ are significantly higher at distances between 0-500 $\mathrm{m}$ compared to the distance of $6 \mathrm{~km} \mathrm{[14].} \mathrm{The} \mathrm{depth} \mathrm{of} \mathrm{penetration} \mathrm{into} \mathrm{the} \mathrm{soil} \mathrm{of} \mathrm{heavy} \mathrm{metals} \mathrm{from} \mathrm{industrial}$ emissions is shallow (up to $15 \mathrm{~cm}$ ) in forest soils and up to $30-40 \mathrm{~cm}$ in arable soils [15].

Vrînceanu et al. [16] have published the results of research on polluted soils from Copsa Mica, showing metal concentrations for $\mathrm{Cu}, \mathrm{Zn}, \mathrm{Pb}$ and $\mathrm{Cd}$ in soil, with values between $69-136 \mathrm{mg} /$ $\mathrm{kg}, 962-2191 \mathrm{mg} / \mathrm{kg}, 1182-1978 \mathrm{mg} / \mathrm{kg}$ and 30-42 mg/kg respectively. In 2002 a study showed that in the soil from Baia Mare the $\mathrm{Cu}$ concentration exceeded 9.5 times the maximum limits and 4.8 times the alert and action limits. The concentration of $\mathrm{Pb}$ exceeded 132 times the alert threshold and 66 times the limit of intervention and the concentration of $\mathrm{Zn}$ exceeded 11 and 6 times these limits respectively [17]. Recent researches in Baia Mare showed some decreasing of heavy metal concentration, but the average values of these concentrations exceed 6 times the maximum level of lead. In the case of $\mathrm{Cu}, \mathrm{Zn}$ and $\mathrm{Cd}$ the average values exceed the maximum level by 10,3 and 7 times. Multiple pollution average index for the four heavy metals 
determines the classification of this area as excessive pollution class (values greater than 16) in the layer of $0-10 \mathrm{~cm}$ and as very strong pollution class in the layer of $10-20 \mathrm{~cm}$. The maximum values of this index reached 78.2 in some excessively polluted areas. In 1994, a land of 21, 875 ha $(3,245$ ha of forest and 18, 630 ha of agricultural land) have been severely affected by heavy metal pollution by exceeding the maximum limits for $\mathrm{Pb}, \mathrm{Cu}, \mathrm{Zn}$ and $\mathrm{Cd}$ [16].

Maximum levels of metal pollution were detected in Baia Mare for $\mathrm{Cd}$, in Copşa Mica for $\mathrm{Pb}$ and Zn, and in Valea Călugărească for Cu [15]. Besides these considerations we can add the ecological accident occurred at Baia Mare in 2000 that led to the contamination of water and soil with cyanide from extraction plants. Specific conditions of those soils (moderate to severe acidity) are favouring the translocation of pollutants from soil to plants, animals and humans, leading to an increase of metal toxicity and a reduction of soil and water quality. Research conducted in 2000 in several areas in the south of Romania have shown the persistence of severe soil pollution with heavy metals in the vicinity of industrial plants (S.C. Neferal and S.C. Acumulatorul-Bucureşti-Pantelimon, S.C. Turnu S.A. - Turnu Măgurele) and pollution with fluoride near ALRO-Slatina.

All these environmental assessments showed the necessity of soil quality improving policy, by changing the land use and by replacing the food crops with industrial crops. Also these areas need measures to reduce the pollution and its toxic effects. Exploit of Romanian peat deposits for the purpose of complete the organic matter of soil, could be a source for improving soil quality and reducing pollution [18].

\subsection{Availability of toxic metal compounds in the soil for plants}

A global statistical evaluation of the substances exchange between soil and plants, led to the conclusion that the percentage itself is influenced by the following parameters:

- Soil texture;

- Carbon content of organic substances;

- Cation exchange capacity of the soil;

- Calcium carbonate equivalent;

- Oxides and hydroxides, mainly Fe, $\mathrm{Mn}$ and $\mathrm{Al}$;

- $\mathrm{pH}$ values - dominant factor.

Soil organic fraction plays an extremely important role because they can delay both the accumulation and transfer of metals and their movement into the soil. Metal toxicity in soil can be increased or reduced by soil organic fraction. Soil $\mathrm{pH}$ directly influences the availability of metals as soil acidity determines solubility of element and its ability to move in the soil solution. Regarding the content of phosphorus in soil, the presence of high doses of $\mathrm{P}_{2} \mathrm{O}_{5}$ can increase or decrease metal uptake. In addition, the accumulation of metals is directly influenced by the plant physiology. For example, Cd uptake in grain has been described to be either antagonistic or synergistic with high concentrations of $\mathrm{Pb}$ in the soil [19]. 
In discussions about soil protection and remediation, pollutant limits for various elements have been established only under certain conditions and soil parameters. It was not taken into account the specific conditions such as the fact that on low-carbon light soils there is strong influence of rainfall leading to a strong acid mobilization and uptake into plants of toxic heavy metals. This does not happen on heavier soils rich in limestone.

The solubility of $\mathrm{Zn}$ in soil was studied by Herms and Brummer [20], which demonstrated the extent to which this element is dissolved by increasing acidity of the soil and became available for plants uptake. A pH value of 5 of low-Zn soil could lead to lasting effect of uptake large amounts of $\mathrm{Zn}$, with all the negative consequences that result. The balance of $\mathrm{Zn}$ in the soil solution is carried out according to the $\mathrm{pH}$ of soil: at $1200 \mathrm{mg} / \mathrm{kg}$ of $\mathrm{Zn}$ and a $\mathrm{pH}$ of 7, at 100 $\mathrm{mg} / \mathrm{kg}$ of $\mathrm{Zn}$ and $\mathrm{pH}$ of 6 , and at only $40 \mathrm{mg} / \mathrm{kg} \mathrm{Zn}$ and a $\mathrm{pH}$ of 5 . This indicates that also the low-Zn soil can store dangerous amounts of available $\mathrm{Zn}$.

\section{Studied area}

Metallurgy activities produce gas, wastewater and waste containing pollutants that can be sources of risk under normal handling, and especially for irresponsible handling of equipment. The main resulted pollutants are: $\mathrm{CO}_{2}, \mathrm{CO}, \mathrm{NO}, \mathrm{SO}$, VOCs (e.g. BaP, PAHs, dioxins, Freon), particulate heavy metals $(\mathrm{Pb}, \mathrm{Cu}, \mathrm{Zn}, \mathrm{As}, \mathrm{Cr})$, cyanides, phenols, heavy metals and sometimes toxic organic compounds in waste material.

Annual average concentrations exceed the maximum permitted levels in many localities (Baia Mare, Copsa Mica, Medias, Targoviste, Arad, Deva, etc.), for both particulate matter and for sediment, coming mainly from industry of steel.

The main polluter from industrial zone of Targoviste city was SC Mechel Targoviste SA, located in the south of the city. By the metallurgical activity, emissions were resulting, with significant concentrations of pollutants, including heavy metals. In the process of obtaining steels at SC Mechel SA, technological flow was served by Electric steelmaking 2, EBT electric oven with a capacity of 70 tons/hour and Continuous casting plant (in billets) with a maximum capacity of production of 2.5 tons/hour. The activity SC Mechel Targoviste SA was assisted by filtration systems so that the environmental impact to be reduced to a lower limit.

During the elaboration of steel in Electric steelmaking no. 2, total dust are emitted to air, metals $\left(\mathrm{Cd} 0.05 \mathrm{mg} / \mathrm{Nm}^{3}, \mathrm{~Pb} 0.3 \mathrm{mg} / \mathrm{Nm}^{3}\right.$ and $\left.\mathrm{Cr}+\mathrm{Cu}+\mathrm{Mn}+\mathrm{Ni}+\mathrm{Zn} 5.0 \mathrm{mg} / \mathrm{Nm}^{3}\right)$, organic compounds, nitrogen oxides (NOx), carbon monoxide (CO) and sulphur oxides (SOx) [21]. In addition to these emissions of heavy metal particulates, SC Mechel SA polluted the soil by the waste and slag dumps generated during the metallurgical processes and stored in an open deposit.

Dispersion of pollutants in the atmosphere largely depends on emission characteristics, meteorological factors, topography, soil roughness, the height of buildings, especially the stack height. Among the meteorological factors, wind direction, intensity, and thereof frequency, are the dominant factors on which we can determine the wind rose indicating the direction of predominant movement of air masses. Based on the wind rose [22] can be designed the 


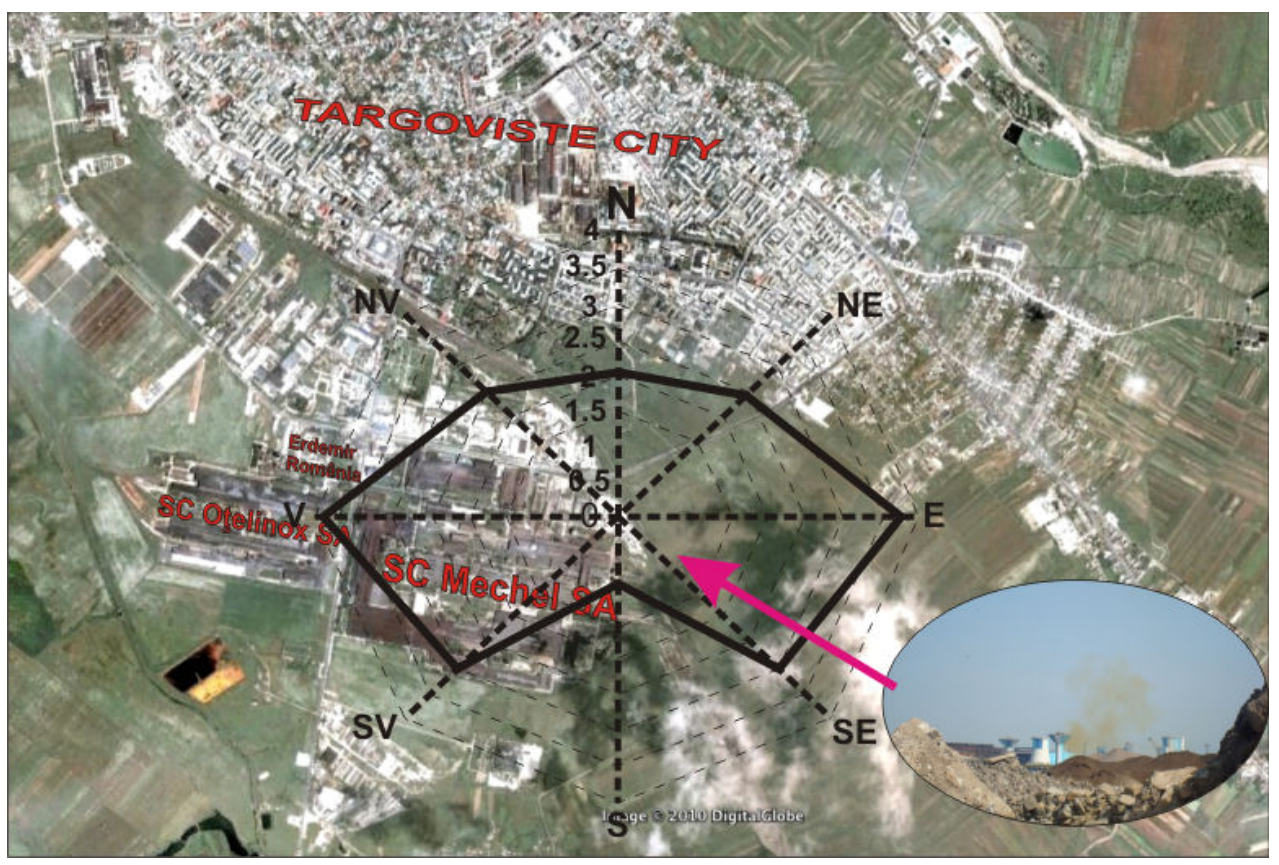

Figure 3. Dispersion and transport of pollutants particles according to the pollution direction compass, relative to the most significant pollution source, the furnace of the Electric steelmaking no. 2 belonging to SC Mechel SA

pollution direction compass which indicates the direction of dispersion and transport of pollutants particles (Figure 3). In the middle of pollution direction compass is the most significant pollution source, the furnace of the Electric steelmaking no. 2 belonging to SC Mechel SA. East was one of the predominant directions of pollutants transport and the particles have deposited on the ground (agricultural fields) during the process of steel elaboration.

In addition to the pollution produced by ground deposition of particles emitted by the SC Mechel SA chimney, these soils are affected by deposit of slag and skim from the same plant. The dumps that are within walking distance (less than $10 \mathrm{~m}$ ) of agricultural land of residents from Colanu, Romania, are subject to a continuous process of erosion and transport by wind, smaller particles from the surface of stockpiles being transported up to $10 \mathrm{~km}$. Dispersion of the slag particles is due to transport activities to and from the place of storage of metal waste.

Characteristic types of soils for studied area are gray luvisol and gray brown luvisol (Figure 4) according SRTS-2003 (reddish brown after SRCS 1980), soils of a reddish hue, quite evident in the upper horizon and really evident in the middle horizon. Water and air permeability of the soil was moderate. Humus content was about 3\%, nutrient supply was moderate, the soil reaction was low-acid with $\mathrm{pH}$ values in the range of 6.0 to 6.4 , and the degree of base saturation was $80 \%$ to $85 \%$. 


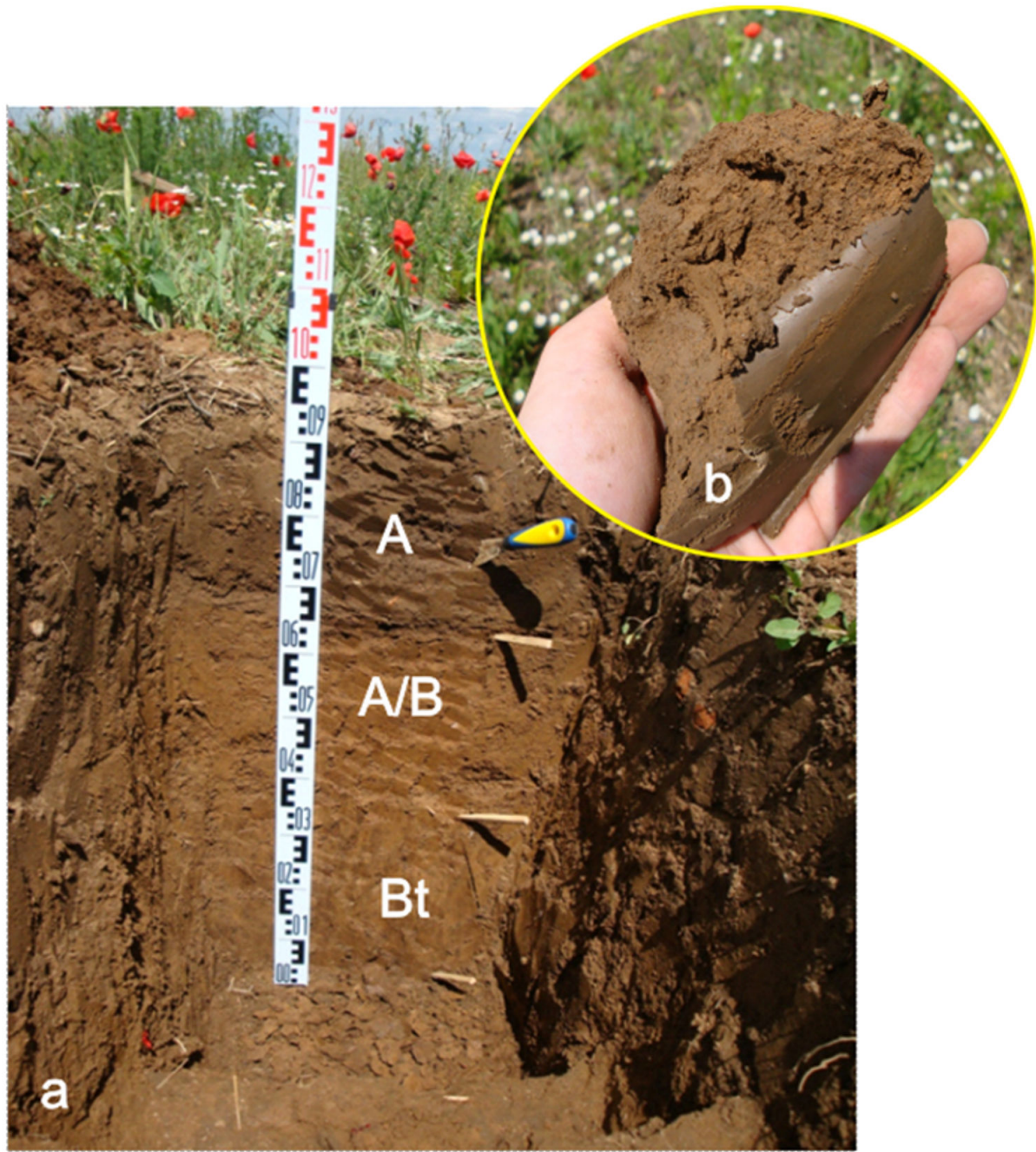

Figure 4. Gray brown luvisol profile (a) and brown-yellowish-rusty upper horizon (b)

Bioaccumulation in upper and middle horizon was low; plant debris was mostly decomposed by the action of fungi, and could be observed the formation of small amounts of humus with predominating fulvic acids. Due to intense alteration of mineral component occurs removal of clay colloid from the surface, with accumulation in the Bt horizon, where the profile shows a textural differentiation.

In soils with alluvial B horizon, such as soil in the industrial area of the Targoviste city, colloidal order mineral fraction of this horizon contains large amounts of colloidal hydroxides (e.g. $\mathrm{Fe}(\mathrm{OH})_{3}$ and $\left.\mathrm{Al}(\mathrm{OH})_{3}\right)$ and various hydrated iron and aluminium sesquioxides free-form 


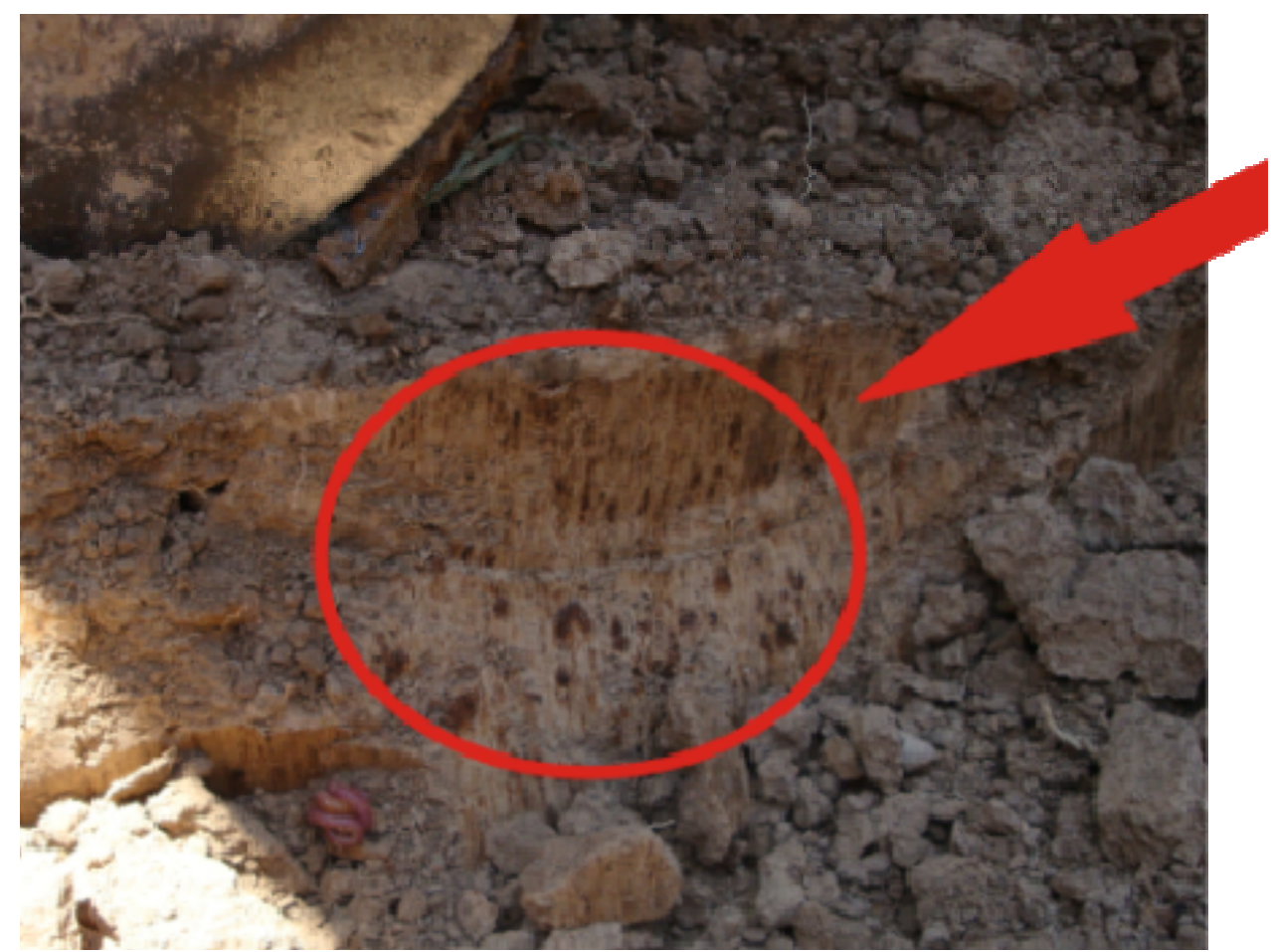

Figure 5. Iron hydroxides

$\left(\mathrm{mR}_{2} \mathrm{O}_{3} \mathrm{nH}_{2} \mathrm{O}\right)$ [23]. Large amounts of iron hydroxides in the humus horizon could be observed for the brown and reddish-brown soils from the industrial zone of Targoviste (Figure 5). The presence of these hydroxides is manifested by brown-yellowish, brown, reddish-brown, yellowish-rusty or rusty lit of the horizon where they are deposited.

\section{Material and method}

\subsection{Experimental design}

Sampling points were chosen to reflect a snapshot of the impact of metallurgical activities in this area by particles emissions. Based on weather conditions and pollution direction compass of Dâmbovița County (Figure 6), were determined that areas found at SW and W towards the emission source are the most affected. In that location have been chosen the harvest area Zone I - industrial fields, with two subzones, for SW and W directions respectively. Land at NE, E and SE from the source of pollution, are grouped according with the use category in Zone II agricultural fields sensitive to high concentrations of heavy metals. 


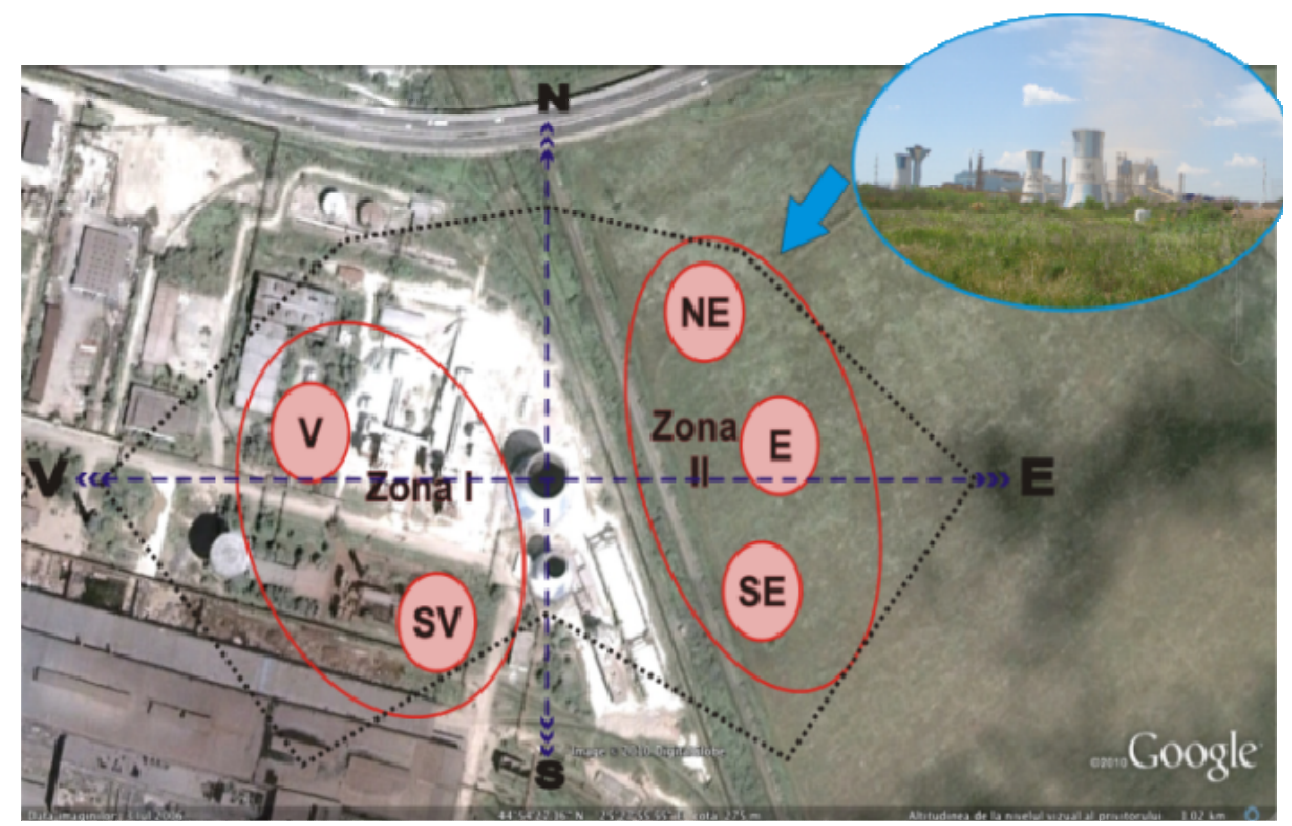

Figure 6. Sampling directions from industrial area of Targoviste city according to the pollution rose

Sampling of soil was done at distances between 50 and 1000 meters from the source of pollution, from five different points, chosen according to triangle method. The results of metal concentration represent the average of these five samples. From each sampling point, samples were taken from three layers: the upper layer ( $0-5 \mathrm{~cm}$ depth), middle layer $(5-20 \mathrm{~cm}$ depth) and lower layer (20-40 cm depth). These layers were chosen according with the depth to which the roots of culture plant normally develop.

The soil samples were processed in the laboratory for elemental analysis by ICP-AES. The soil samples were dried at $40^{\circ} \mathrm{C}$ for 24 hours, ground to a fine powder, sieved at $250 \mu \mathrm{m}$ (according to SR ISO 11464).

\subsection{Analytical methods}

Determination of heavy metal concentration in soil was done on replicates samples by Inductively Coupled Plasma - Atomic Emission Spectrometry method (ICP-AES). The soils samples were mineralized in Berghof microwave digester, using a mixture 1:1 with nitric acid (according with Berghof method) prior to ICP-AES analyses. The advantage of ICP-AES is the multielemental detection $(\mathrm{Cu}, \mathrm{Zn}, \mathrm{Sn}, \mathrm{Pb}, \mathrm{Co}, \mathrm{Ni}, \mathrm{Mn}, \mathrm{Cr}$ and $\mathrm{Mo}$ ) [24]. For this research, analyses were conducted with Liberty 110 spectrometer of Varian brand. The minimal detection limits of device range according to the analysed element and is $0.4 \mathrm{mg} / \mathrm{kg}$ for $\mathrm{Zn}, \mathrm{Mn}$ 
and $\mathrm{Cu} ; 0.5 \mathrm{mg} / \mathrm{kg}$ for $\mathrm{Cr}$ and $\mathrm{Co} ; 0.6 \mathrm{mg} / \mathrm{kg}$ for $\mathrm{Sn}, \mathrm{Ni}$ and $\mathrm{Pb}$. The concentrations values for analysed metals were expressed in milligrams of metal per kilogram of dry soil (mg/kg).

The soil $\mathrm{pH}$ was determined with a portable $\mathrm{pH}$-meter, WTW 3110 SET 2, with precision of 0.01 units. For $\mathrm{pH}$ analyses, $5 \mathrm{~g}$ of each soil sample were mixed with $50 \mathrm{ml} \mathrm{KCl} 0.1 \mathrm{~N}, \mathrm{~F} 1000$, Tt $0.0056 \mathrm{~g} / \mathrm{ml}$ and homogenized for 15 minutes with a magnetic stirrer.

\section{Results}

\subsection{Statistical results of heavy metal concentration}

In the industrial area of Targoviste city, the concentration of heavy metals in soil was highly dependent on the metal species, the position of sampling point towards the source of pollution, the stack, and the depth of sampling. The general statistical results of heavy metal concentration in studied area are presented in Table 2.

The variation of $\mathrm{Cu}$ concentration in the $0-5 \mathrm{~cm}$ layer of soil was higher than the variation on the profile. Cu concentration ranged from $578.4 \mathrm{mg} / \mathrm{kg}$ in the surface layer, to $170.4 \mathrm{mg} / \mathrm{kg}$ ( 5 $-20 \mathrm{~cm})$ and $152.4 \mathrm{mg} / \mathrm{kg}(20-40 \mathrm{~cm})$. The Cu concentration variation showed that $75 \%$ of the samples had values of concentration up to $135.9 \mathrm{mg} / \mathrm{kg}$, and only $25 \%$ of the samples had higher concentrations than this value. The same pattern of variation of $\mathrm{Cu}$ concentration was followed for the deeper layers. For the layer of 5-20 cm depth, most samples (75\%) had concentrations within a narrow range, from 28.7 to $43.6 \mathrm{mg} / \mathrm{kg}$ and for the layer of $20-40 \mathrm{~cm}$ depth $75 \%$ of samples range between 22.0 to $55.2 \mathrm{mg} / \mathrm{kg}$.

The variation of $Z$ n concentration was very high at the surface of soil profile $(827.7 \mathrm{mg} / \mathrm{kg})$ and lower in the deeper layers of soil $(128.8 \mathrm{mg} / \mathrm{kg}$ and $186.9 \mathrm{mg} / \mathrm{kg}$ respectively. In all the three studied layers, the concentration of $\mathrm{Zn}$ in most of the samples was placed in a very small range as compared to the magnitude of total concentration range. In the surface layer, $50 \%$ of the samples showed a concentration of Zn from 42.6 to $86.1 \mathrm{mg} / \mathrm{kg}$ and $75 \%$ were found between 42.64 to $225.03 \mathrm{mg} / \mathrm{kg}$. The same pattern of distribution of $\mathrm{Zn}$ concentration was followed in the deeper layers, $75 \%$ of the samples being in a relatively narrow range of concentration from 44.4 to $72.9 \mathrm{mg} / \mathrm{kg}$ for the depth of $5-20 \mathrm{~cm}$ and 33.1 to $81.8 \mathrm{mg} / \mathrm{kg}$ for the layer of $20-40 \mathrm{~cm}$ depth.

The values of Sn concentration showed a higher homogeneity in soil when compared to $\mathrm{Cu}$ and $\mathrm{Zn}$ concentration. Sn concentration ranged from $92.7 \mathrm{mg} / \mathrm{kg}$ at the surface of profile to about $40 \mathrm{mg} / \mathrm{kg}$ in deeper layers $(5-40 \mathrm{~cm})$. The four quadrants of $S n$ concentration distribution showed narrow values, though there was a concentration of Sn values $(50 \%)$ in the range 32.7 to $53.9 \mathrm{mg} / \mathrm{kg}$ for $0-5 \mathrm{~cm}$ layer. In the middle layer $(5-20 \mathrm{~cm})$, about $75 \%$ of the sample ranged from $<$ LD to $20.9 \mathrm{mg} / \mathrm{kg}$. At $20-40 \mathrm{~cm}$ depth, quadrants II and III of the concentration distribution were distributed on the interval from 15.39 to $22.8 \mathrm{mg} / \mathrm{kg}$, the remaining $50 \%$ of the samples having values lower or higher than this range. 


\begin{tabular}{|c|c|c|c|c|c|c|c|c|}
\hline Metal & Depth & Mean \pm SD & Min-Max & Median & Q1 & Q3 & Skewness & Kurtosis \\
\hline \multirow[t]{3}{*}{$\mathrm{Cu}$} & $0-5 \mathrm{~cm}$ & $125.5 \pm 162.6$ & $22.0-600.4$ & 36.5 & 30.9 & 135.9 & 2.1185 & 4.6664 \\
\hline & $5-20 \mathrm{~cm}$ & $61.1 \pm 55.0$ & 28.7-199.1 & 35.1 & 32.5 & 43.6 & 1.8284 & 1.9995 \\
\hline & $20-40 \mathrm{~cm}$ & $63.3 \pm 53.1$ & $22.0-174.5$ & 38.1 & 35.4 & 55.2 & 1.5680 & 0.7874 \\
\hline \multirow[t]{3}{*}{$\mathrm{Zn}$} & $0-5 \mathrm{~cm}$ & $223.9 \pm 269.0$ & $42.6-870.3$ & 86.1 & 73.3 & 225.0 & 1.6278 & 1.3552 \\
\hline & $5-20 \mathrm{~cm}$ & $74.3 \pm 42.9$ & $44.4-173.2$ & 54.1 & 48.4 & 72.9 & 1.5888 & 1.0601 \\
\hline & $20-40 \mathrm{~cm}$ & $75.6 \pm 50.61$ & $33.1-220.1$ & 53.1 & 49.4 & 81.8 & 1.9591 & 4.0515 \\
\hline \multirow[t]{3}{*}{ Sn } & $0-5 \mathrm{~cm}$ & $65.1 \pm 30.2$ & $32.7-125.4$ & 53.9 & 41.9 & 84.8 & 0.7305 & -0.7436 \\
\hline & $5-20 \mathrm{~cm}$ & $12.9 \pm 12.9$ & $<$ LD-44.4 & 14.9 & $<\mathrm{LD}$ & 20.9 & 0.8094 & 0.8786 \\
\hline & $20-40 \mathrm{~cm}$ & $17.8 \pm 10.9$ & $<$ LD-38.2 & 19.4 & 15.4 & 22.8 & -0.3501 & 0.0826 \\
\hline \multirow[t]{3}{*}{$\mathrm{Pb}$} & $0-5 \mathrm{~cm}$ & $76.4 \pm 98.9$ & $0.6-294.3$ & 43.3 & 0.66 & 92.1 & 1.3987 & 0.8529 \\
\hline & $5-20 \mathrm{~cm}$ & $47.9 \pm 42.6$ & $<\mathrm{LD}-121.0$ & 42.5 & 20.86 & 64.1 & 0.7683 & -0.5585 \\
\hline & $20-40 \mathrm{~cm}$ & $34.0 \pm 43.6$ & $<$ LD-145.6 & 26.3 & $<\mathrm{LD}$ & 35.6 & 1.5800 & 2.0421 \\
\hline \multirow[t]{3}{*}{ Co } & $0-5 \mathrm{~cm}$ & $16.2 \pm 4.8$ & $7.1-23.5$ & 17.3 & 12.9 & 19.1 & -0.5281 & -0.4808 \\
\hline & $5-20 \mathrm{~cm}$ & $14.7 \pm 5.1$ & $6.7-21.5$ & 13.6 & 10.3 & 19.4 & -0.0702 & -1.6268 \\
\hline & $20-40 \mathrm{~cm}$ & $13.1 \pm 4.0$ & 6.7-19.9 & 14.9 & 9.5 & 15.6 & -0.3423 & -0.9854 \\
\hline \multirow[t]{3}{*}{$\mathrm{Ni}$} & $0-5 \mathrm{~cm}$ & $65.1 \pm 58.5$ & $13.8-185.4$ & 37.6 & 22.0 & 84.8 & 1.0999 & -0.1291 \\
\hline & $5-20 \mathrm{~cm}$ & $20.2 \pm 15.9$ & $8.7-52.7$ & 13.1 & 12.3 & 14.8 & 1.6371 & 0.8719 \\
\hline & $20-40 \mathrm{~cm}$ & $23.2 \pm 23.9$ & $4.4-72.4$ & 14.2 & 8.3 & 17.7 & 1.5576 & 0.7595 \\
\hline \multirow[t]{3}{*}{ Mn } & $0-5 \mathrm{~cm}$ & $1579.7 \pm 352.3$ & 1159.9-2348.0 & 1419.1 & 1373.2 & 1731.3 & 0.9420 & 0.0714 \\
\hline & $5-20 \mathrm{~cm}$ & $1348.9 \pm 243.6$ & 758.9-1677.3 & 1384.1 & 1322.7 & 1504.3 & -1.2771 & 1.5204 \\
\hline & $20-40 \mathrm{~cm}$ & $1367.5 \pm 327.9$ & 720.4-1763.1 & 1486.3 & 1258.4 & 1601.1 & -1.0239 & -0.1494 \\
\hline \multirow[t]{3}{*}{$\mathrm{Cr}$} & $0-5 \mathrm{~cm}$ & $114.6 \pm 125.5$ & $13.7-315.6$ & 25.1 & 21.6 & 205.7 & 0.7343 & -1.3288 \\
\hline & $5-20 \mathrm{~cm}$ & $46.0 \pm 51.7$ & $16.2-168.3$ & 22.7 & 17.81 & 30.4 & 1.7522 & 1.5205 \\
\hline & $20-40 \mathrm{~cm}$ & $41.0 \pm 52.9$ & $8.2-159.9$ & 18.3 & 13.8 & 21.5 & 1.6981 & 1.1754 \\
\hline \multirow[t]{3}{*}{ Mo } & $0-5 \mathrm{~cm}$ & $7.2 \pm 7.8$ & $0.6-23.4$ & 4.5 & 0.6 & 10.5 & 1.0334 & -0.1858 \\
\hline & $5-20 \mathrm{~cm}$ & $3.0 \pm 3.4$ & $<$ LD-10.8 & 1.2 & 0.7 & 5.1 & 1.1289 & 0.2488 \\
\hline & $20-40 \mathrm{~cm}$ & $2.4 \pm 3.3$ & $<$ LD-9.7 & 1.0 & 0.6 & 1.6 & 1.6104 & 0.9883 \\
\hline
\end{tabular}

Table 2 Statistical results of heavy metal concentration $(\mathrm{mg} / \mathrm{kg})$ in soil surrounding the industrial area of Targoviste city

The variability of $\mathrm{Pb}$ concentration was very high, most of the samples showing very low levels, even below the detection limit of the analytical method, in the entire soil profile studied, while some samples presented significant concentrations of $\mathrm{Pb}$ up to $294.3 \mathrm{mg} / \mathrm{kg}(0-5 \mathrm{~cm}), 121.0 \mathrm{mg} /$ 
$\mathrm{kg}$ ( 5 to $20 \mathrm{~cm}$ deep) and $145.6 \mathrm{mg} / \mathrm{kg}(20-40 \mathrm{~cm})$. The distribution of the samples in terms of the concentration was varying, $75 \%$ of the samples from the surface of soil profile were in the range of concentrations from 0 to $92.1 \mathrm{mg} / \mathrm{kg}$, and the remaining $25 \%$ were in the range of 92.1 to $294.3 \mathrm{mg} / \mathrm{kg}$. The $\mathrm{Pb}$ distribution was less variable in the deeper layers, the four quadrants of the concentration being distributed at relatively equal intervals, especially for the depth 5-20 $\mathrm{cm}$. Heterogeneity of the sample in terms of the concentration of lead in the ground was indicated by the high value of the standard deviation, higher than the average concentration throughout the studied soil profile.

The concentrations of $\mathrm{Co}$ in the samples were distributed homogeneously throughout the range of concentrations for both the upper layer and deeper layers of 5-20 cm and 20-40 cm respectively. The homogeneity of the samples was indicated by the low values of standard deviation, between $29 \%$ and $34 \%$ of the average, and by the median value that was very close to the average value, $17.3 \mathrm{mg} / \mathrm{kg}, 13.6 \mathrm{mg} / \mathrm{kg}$, respectively $14.9 \mathrm{mg} / \mathrm{kg}$ for the three depths. On the surface of the soil profile, $50 \%$ of the analysed samples were in the range of concentration from 12.9 to $19.1 \mathrm{mg} / \mathrm{kg}$.

In surface layer of soil, the range of Ni concentration varied widely, up to $185.4 \mathrm{mg} / \mathrm{kg}$. The soil sample from surface layer presented heterogeneous distribution of $\mathrm{Ni}$, with $75 \%$ of the samples from $0-5 \mathrm{~cm}$ depth showing a concentration ranging 13.8 to $84.8 \mathrm{mg} / \mathrm{kg}$, and only $25 \%$ of the samples ranging 84.8 to $185.4 \mathrm{mg} / \mathrm{kg}$. The Ni concentration variation was lower in deeper layers; most of the samples (75\%) were covered by a much narrower range of concentration from 8.7 to $14.8 \mathrm{mg} / \mathrm{kg}$ for $5-20 \mathrm{~cm}$ depth, and 4.4 to $17.7 \mathrm{mg} / \mathrm{kg}$ for $20-40 \mathrm{~cm}$ depth.

Distribution of samples within the range of Mn concentration was uniform and $50 \%$ of the samples were within the range of 1373.2 to $1731.3 \mathrm{mg} / \mathrm{kg}$, while the remaining $50 \%$ of the samples from the surface of the soil profile were higher or lower than this range. The same pattern of samples distribution was followed in the deeper layers, where $50 \%$ of the samples were concentrated in the middle of the range of Mn concentration. The standard deviation of the Mn concentration indicates that the samples had similar values of concentration for each layer, accounting $22 \%, 18 \%$ and $24 \%$ respectively for the three layers of $0-5 \mathrm{~cm}, 5-20 \mathrm{~cm}$ and $20-40 \mathrm{~cm}$.

The wide variation of $\mathrm{Cr}$ concentration in the samples was reflected by the high value of standard deviation, greater than the average concentration for all three depths. Half of the samples from $0-5 \mathrm{~cm}$ layer of soil showed $\mathrm{Cr}$ concentrations in a very small range between 13.7 and $25.1 \mathrm{mg} / \mathrm{kg}$. The remaining $50 \%$ of the samples were distributed in a wider concentration range between 25.1 and $315.6 \mathrm{mg} / \mathrm{kg}$. At depths greater than $5 \mathrm{~cm}, 75 \%$ of the investigated samples had concentrations of $\mathrm{Cr}$ in a narrow range of $14.2 \mathrm{mg} / \mathrm{kg}$ for the depth of $5-20 \mathrm{~cm}$ and $13.3 \mathrm{mg} / \mathrm{kg}$ for the depth of $20-40 \mathrm{~cm}$, while the remaining $25 \%$ had concentrations in the range of $137.9 \mathrm{mg} / \mathrm{kg}$ and $138.4 \mathrm{mg} / \mathrm{kg}$ respectively for the two layers of soil.

The range of Mo concentration was higher in the surface of soil profile $(22.8 \mathrm{mg} / \mathrm{kg})$ compared to the range of concentration of deeper layers of soil $(10.8 \mathrm{mg} / \mathrm{kg}$ and $9.7 \mathrm{mg} / \mathrm{kg}$ respectively). The majority of samples (75\%) showed low levels of Mo, up to $10.5 \mathrm{mg} / \mathrm{kg}$ on the surface and $5.1 \mathrm{mg} / \mathrm{kg}$ and $1.6 \mathrm{mg} / \mathrm{kg}$ in the deeper layers of $5-20 \mathrm{~cm}$ and $20-40 \mathrm{~cm}$ 
respectively. The concentration varied greatly, with values of standard deviation higher than the mean concentration.

\subsection{Horizontal distribution of heavy metals}

The horizontal distribution of heavy metals and level of metal pollution in the industrial area of Targoviste city was established by comparing to the Romanian legislation [3], which regulates normal values, alert thresholds and action levels for different trace elements by use of soils, agricultural and industrial land (Table 3).

\begin{tabular}{llllllllll}
\hline Limit & $\mathbf{C u}$ & $\mathbf{Z n}$ & $\mathbf{S n}$ & $\mathbf{P b}$ & $\mathbf{C o}$ & $\mathbf{N i}$ & $\mathbf{M n}$ & $\mathbf{C r}$ & $\mathbf{M o}$ \\
\hline NV & 20 & 100 & 20 & 20 & 15 & 20 & 900 & 30 & 2 \\
\hline ATA & 100 & 300 & 35 & 50 & 30 & 75 & 1500 & 100 & 5 \\
\hline ATI & 250 & 700 & 100 & 250 & 100 & 200 & 2000 & 300 & 15 \\
\hline
\end{tabular}

NV - normal values; ATA - alert threshold for agricultural soil; ATI - alert threshold for industrial soil

Table 3 Normal values and alert thresholds of heavy metal concentration $(\mathrm{mg} / \mathrm{kg}$ ) for agricultural and industrial soil in Romania [3]

The concentration of $\mathrm{Cu}$ on the surface layer of soil differed greatly between the two studied zones (I and II) (Table 4). Thus, in Zone I, on the SW and W directions towards the emission source, the concentration of Cu reached $401.44 \mathrm{mg} / \mathrm{kg}$ and $134.58 \mathrm{mg} / \mathrm{kg}$, values of 7 to 20 times higher than normal levels in this category of soils [25]. In Zone II, the concentrations of $\mathrm{Cu}$ on the NE, E and SE directions were slightly greater than the normal value of concentration, ranging between 22.37 and $36.61 \mathrm{mg} / \mathrm{kg}$.

In the case of $\mathrm{Zn}$, the maximum values allowed for industrial soil, $700 \mathrm{mg} / \mathrm{kg}$ were overcome on $\mathrm{W}$ direction to the source, while the value on SW direction was below that limit, but exceeded the normal value of $\mathrm{Zn}$ in soil. The soils in Zone II showed a deficiency of $\mathrm{Zn}$ at surface layer and in the deeper layers. In the upper horizon, the $\mathrm{Zn}$ concentration was between 46.03 and $86.07 \mathrm{mg} / \mathrm{kg}$, values that are below the normal value of this element in soil [26].

Sn concentrations in the analysed soils were above normal values (Table 4) in both the Zone I and Zone II. A concentration of about 6 times the normal limit was found in soils under the SW direction. For other samples, the concentration of Sn in soil ranged from 33.77 to $82.90 \mathrm{mg} /$ $\mathrm{kg}$, the lowest value being on E direction and the highest on SE direction.

Although the normal value of $\mathrm{Pb}$ in soil is $20 \mathrm{mg} / \mathrm{kg}$, the concentration of this element in the studied samples of soils did not exceed the threshold. The soil in Zone II showed the lowest concentration. In the SE direction, $\mathrm{Pb}$ concentration in soil was the highest, $43.35 \mathrm{mg} / \mathrm{kg}$. The soil in the Zone I, showed values of $\mathrm{Pb}$ concentration that exceeded 4 to 12 times the normal values: $85.38 \mathrm{mg} / \mathrm{kg}$ in the SW direction and $252.00 \mathrm{mg} / \mathrm{kg}$ on the $\mathrm{W}$ direction.

The concentrations of Co in soils were not much higher than the normal values of metal concentration in soil. Higher values were found in the soil from Zone I, $19.93 \mathrm{mg} / \mathrm{kg}$ in the W 


\begin{tabular}{|c|c|c|c|c|c|}
\hline \multirow{2}{*}{ Heavy metal } & \multicolumn{5}{|c|}{ Direction towards the emission source } \\
\hline & SV & V & NE & $\mathbf{E}$ & SE \\
\hline $\mathrm{Cu}$ & 401.44 & 134.58 & 32.41 & 22.37 & 36.61 \\
\hline $\mathrm{Zn}$ & 194.28 & 719.13 & 74.45 & 46.03 & 86.07 \\
\hline Sn & 112.31 & 52.79 & 43.78 & 33.77 & 82.90 \\
\hline $\mathrm{Pb}$ & 85.38 & 252.00 & 0.60 & 0.76 & 43.25 \\
\hline Co & 20.42 & 19.93 & 14.11 & 8.94 & 17.48 \\
\hline $\mathrm{Ni}$ & 166.64 & 83.84 & 15.01 & 22.42 & 37.39 \\
\hline Mn & 1264.26 & 2156.48 & 1726.44 & 1362.45 & 1388.85 \\
\hline $\mathrm{Cr}$ & 200.31 & 312.33 & 13.88 & 24.98 & 21.68 \\
\hline \multirow[t]{2}{*}{ Mo } & 9.79 & 0.6 & 20.57 & 0.65 & 4.45 \\
\hline & Under normal limit & & limit & for agricultural & $\begin{array}{l}\text { d the alert } \\
\text { old for industrial }\end{array}$ \\
\hline
\end{tabular}

Table 4 Horizontal distribution of heavy metal concentrations $(\mathrm{mg} / \mathrm{kg})$ in the industrial area of Târgovişte city

direction and $20.42 \mathrm{mg} / \mathrm{kg}$ in the SW direction. The soils in the Zone II showed values of Co concentrations that varied between 8.94 and $17.48 \mathrm{mg} / \mathrm{kg}$. The lowest value was on E direction, and the highest value on SE direction.

The concentration of $\mathrm{Ni}$ in soils varied widely in the two studied zones. In Zone I, the concentration of $\mathrm{Ni}$ was between 4 and 8 times higher than the normal value of metal concentration in soil, $83.84 \mathrm{mg} / \mathrm{kg}$ in the W direction and $166.64 \mathrm{mg} / \mathrm{kg}$ on the SW direction. The soil in Zone II showed Ni concentration close to normal values, ranging from 15.01 to $37.39 \mathrm{mg} / \mathrm{kg}$. The highest value was for the Ni concentration on SE direction.

Concentration of $\mathrm{Mn}$ in the soil was two times higher than the normal value and range between $1264.26 \mathrm{mg} / \mathrm{kg}$ and $2156.48 \mathrm{mg} / \mathrm{kg}$. The lowest value of Mn concentration was on SW direction and the higher on the $\mathrm{W}$ direction.

Concentrations of $\mathrm{Cr}$ in soils from the industrial area were very different between the two studied zones. In Zone I, the concentrations were extremely high compared to the normal limit (30 mg/kg), reaching values over 10 times higher: $200.33 \mathrm{mg} / \mathrm{kg}$ and $312.33 \mathrm{mg} / \mathrm{kg}$ on SW and $\mathrm{W}$ directions respectively. In Zone II, Cr concentration showed values below the normal concentration of $\mathrm{Cr}$ in this type of soil, and varied between 13.88 and $24.98 \mathrm{mg} / \mathrm{kg}$ [27].

Molybdenum concentration in the surface layer of soil varied within wide limits, irrespective of the position towards the source of pollution. In Zone I, concentration of Mo has the minimum value in the $\mathrm{W}$ direction $(0.6 \mathrm{mg} / \mathrm{kg})$, and the maximum value in the $\mathrm{SW}$ direction $(9.79 \mathrm{mg} /$ $\mathrm{kg}$ ). This value was about 5 times higher than the normal value of Mo concentration in soil. In Zone II, the concentration of this metal varied also within wide limits, from $0.65 \mathrm{mg} / \mathrm{kg}$ in the 
E direction to $20.57 \mathrm{mg} / \mathrm{kg}$ in the NE direction. The recorded values were more than 10 times higher than normal values.

\subsection{Vertical distribution of heavy metals}

The vertical distribution of heavy metals in the soil profile $(0-40 \mathrm{~cm})$ is shown in figures $7-$ 14 , which indicates the level of heavy metals in the three soil layers: $0-5 \mathrm{~cm}, 5-20 \mathrm{~cm}$ and 20 $-40 \mathrm{~cm}$. For each layer, linear regression was calculated to indicate correlations of heavy metal concentrations with the $\mathrm{pH}$.

The high concentrations of $\mathrm{Cu}$ in the SW direction were maintained at very high level in the depth of soil profile (Figure 7). In the $\mathrm{W}$ direction, $\mathrm{Cu}$ concentration decrease to depth of 40 $\mathrm{cm}$ to levels of $27 \mathrm{mg} / \mathrm{kg}$. The soil in Zone II showed similar values of $\mathrm{Cu}$ concentration on the entire profile of soil. Between the $\mathrm{Cu}$ concentration and the $\mathrm{pH}$ of soil was observed a moderate correlation in the surface layer of soil (0.3) and very low correlations for the two deeper layers. All the correlations were positive.

Extremely high $\mathrm{Zn}$ concentration from the surface layer of soil did not maintained in depth. Below $5 \mathrm{~cm}$ depth the concentration of $\mathrm{Zn}$ decreased to values lower than $35 \mathrm{mg} / \mathrm{kg}$ (Figure 8). In the SW direction, the concentration of $\mathrm{Zn}$ in the deeper layers of soil remained at levels comparable to the surface layer, ranging between 154.38 and $194.28 \mathrm{mg} / \mathrm{kg}$. The lowest values were in the middle of the soil profile, and the highest values on surface layer. The design of the $\mathrm{Zn}$ distribution in soil was maintained in Zone II. The highest concentrations were on the surface, decreased in the middle of soil profile, and increased in the lower part of the profile. The concentrations of $\mathrm{Zn}$ to this area were between 46.03 and $86.07 \mathrm{mg} / \mathrm{kg}$. Correlation between the $\mathrm{Zn}$ concentrations in the soil with its $\mathrm{pH}$ is strong in the upper layer $(0.48)$, and very low to depth.

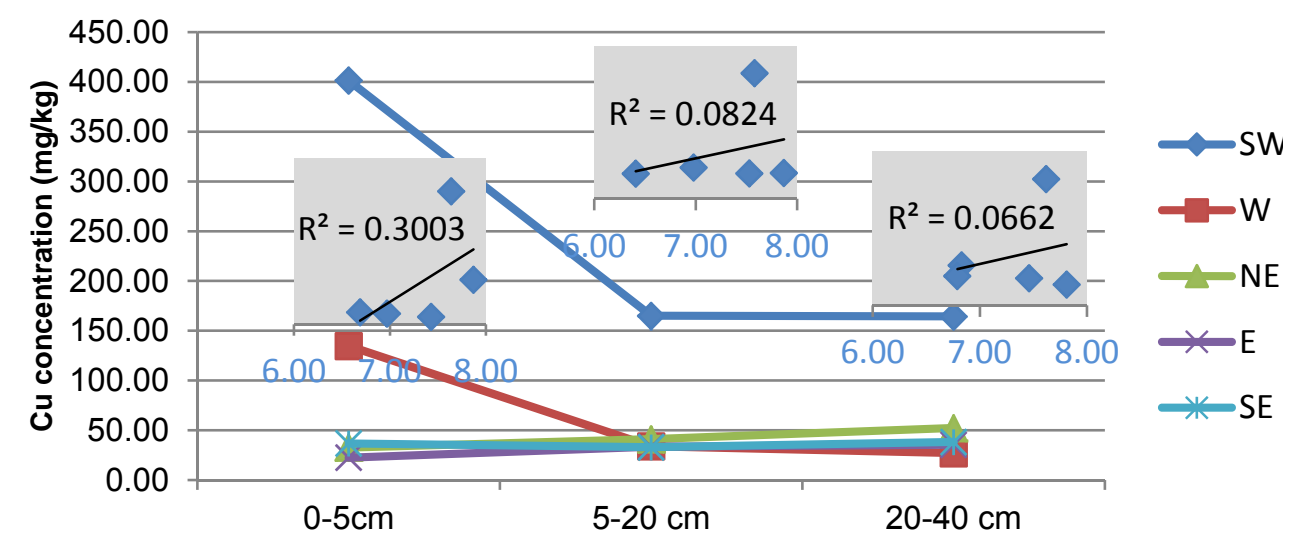

Figure 7. Copper vertical distribution in soil and correlation with $\mathrm{pH}$ 


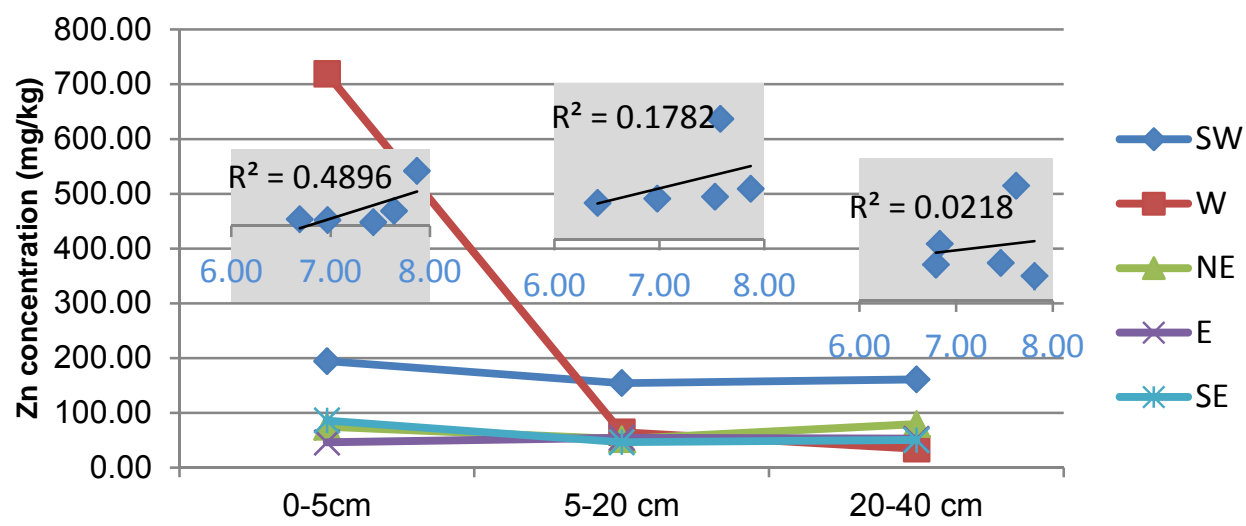

Figure 8. Zinc vertical distribution in soil and correlation with $\mathrm{pH}$

In contrast to $\mathrm{Cu}$ and $\mathrm{Zn}$, Sn distribution in the soil profile showed a very wide variance (Figure 9). The surface layer showed Sn concentration much higher than in depth. For all studied direction, was observed that the concentration of Sn decreased towards the centre, and grow on the bottom of the profile. Correlation between the $\mathrm{Sn}$ concentrations and the $\mathrm{pH}$ of soil is positive, but to a different extent, depending on the depth. Thus, the surface layer had a very low correlation, in the 5-20 cm layer the correlation was low, and the bottom of soil profile the correlation was moderate $(>0.4)$.

Distribution of $\mathrm{Pb}$ in the soil did not follow a pattern, but varied from one area to another. Thus, the high $\mathrm{Pb}$ concentration from the surface, in the $\mathrm{W}$ direction, decreased sharply towards the middle of soil profile, and continues to decrease to the bottom of the profile (Figure 10). In the $\mathrm{SW}$ and $\mathrm{E}$ directions, the $\mathrm{Pb}$ concentration was higher in the middle and lower soil profile than in the upper horizon, far exceeding the normal value of $\mathrm{Pb}$ concentration in soil. In the $\mathrm{NE}$ and $\mathrm{SE}$ directions, $\mathrm{Pb}$ concentrations were similar throughout the entire soil profile. The correlation between the $\mathrm{Pb}$ concentrations in soil and the $\mathrm{pH}$ decreased from the surface to the depth of soil profile. The correlation was moderate positive in the upper layer $(0.47)$, and low but positive to the bottom of soil profile.

The distribution of Co on the soil profile varied from one point to another (Figure 11). In the SW, SE and E directions, the Co concentration in the soil increased slightly in the middle of soil profile and decreased sharply towards the bottom of it. In the $\mathrm{W}$ direction, the Co concentration decreased sharply towards the centre of soil profile and continues to decrease to the bottom thereof. In the NE direction, the Co concentration is higher in the lower part of the profile as compared to the upper layers. The correlation between the Co concentrations in soil and $\mathrm{pH}$ varied on the soil profile as intensity. In the upper layers, the correlation is positive, but very low $(<0.2)$, while the lower layers showed weak negative correlation (0.2 - 0.4$)$.

Nickel concentration varied along the profile of soil. Much higher values were observed in the surface layer of soil compared to the values representing the concentration of $\mathrm{Ni}$ in the middle of the profile. At the bottom of the profile, the concentrations increased slightly (Figure 12). 


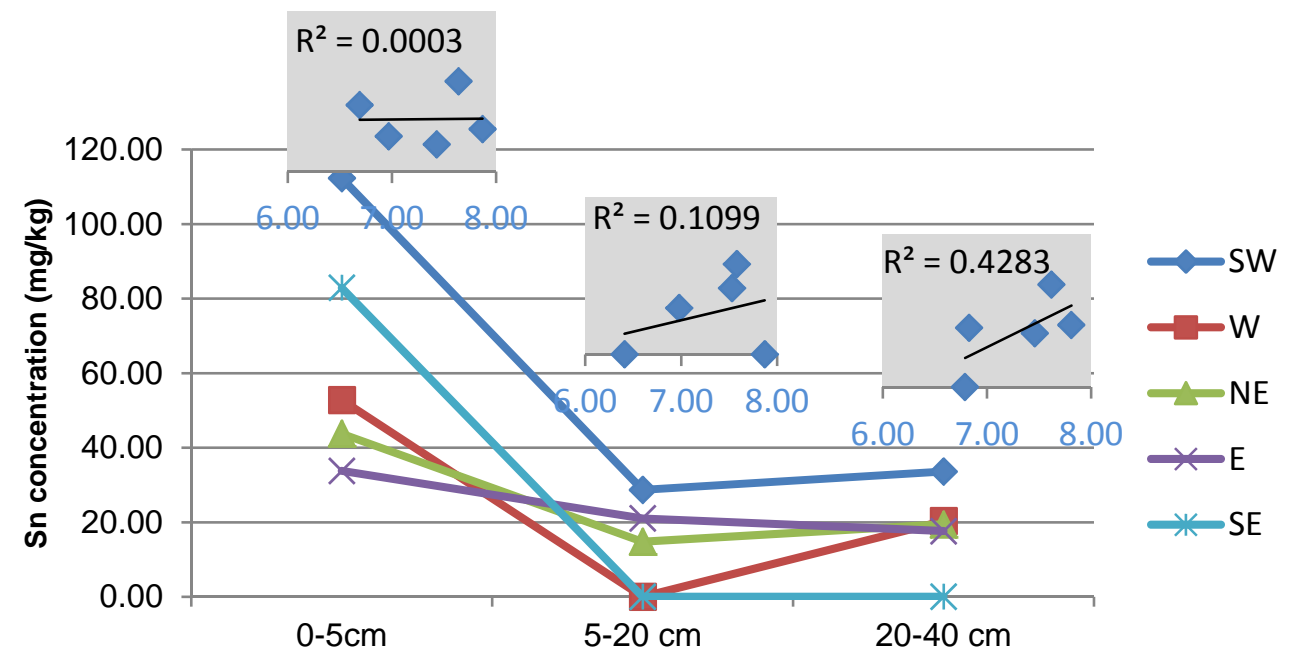

Figure 9. Tin vertical distribution in soil and correlation with $\mathrm{pH}$

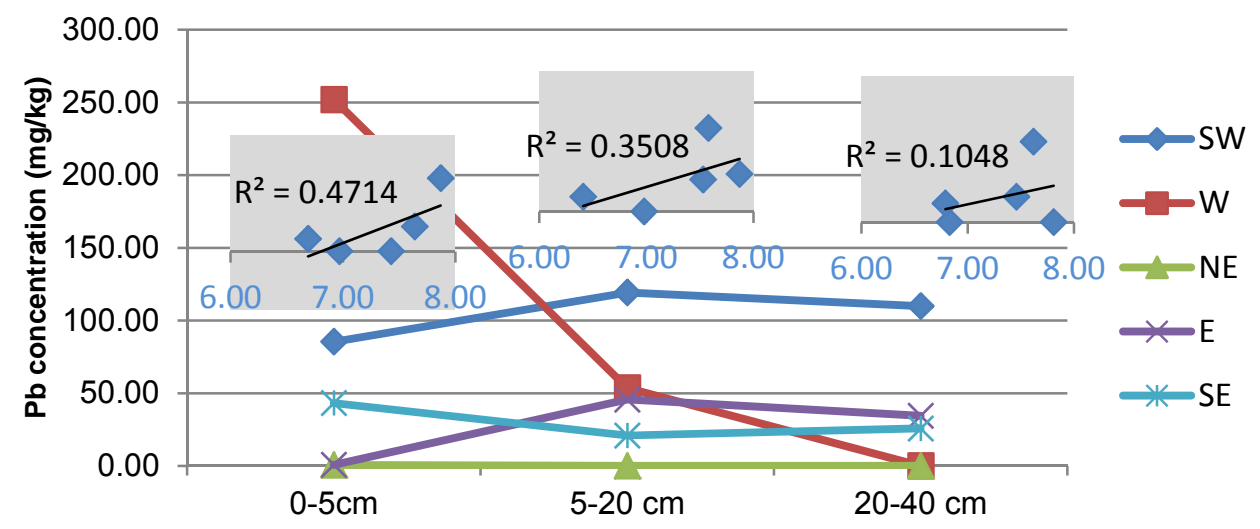

Figure 10. Lead vertical distribution in soil and correlation with $\mathrm{pH}$

For soil samples collected in the SW direction, the metal concentrations maintained at high value on the entire soil profile compared to other directions. In the W direction, the surface layer showed much higher concentrations of $\mathrm{Ni}$, and in the deeper layers the value of $\mathrm{Ni}$ concentration were still high. The correlation between the Ni concentrations in soil and the $\mathrm{pH}$ was low, positive and decreased in intensity with the depth profile.

Except for samples collected west from the pollution source, distribution of Mn was approximately uniform throughout the soil profile, the concentration ranging between $942.32 \mathrm{mg} / \mathrm{kg}$ and $1578.64 \mathrm{mg} / \mathrm{kg}$ at 5-20 $\mathrm{cm}$ depth, and between 796.68 and $1631.13 \mathrm{mg} / \mathrm{kg}$ at 20-40 $\mathrm{cm}$ depth (Figure 13). The surface layer showed a low correlation between the Mn concentrations and 


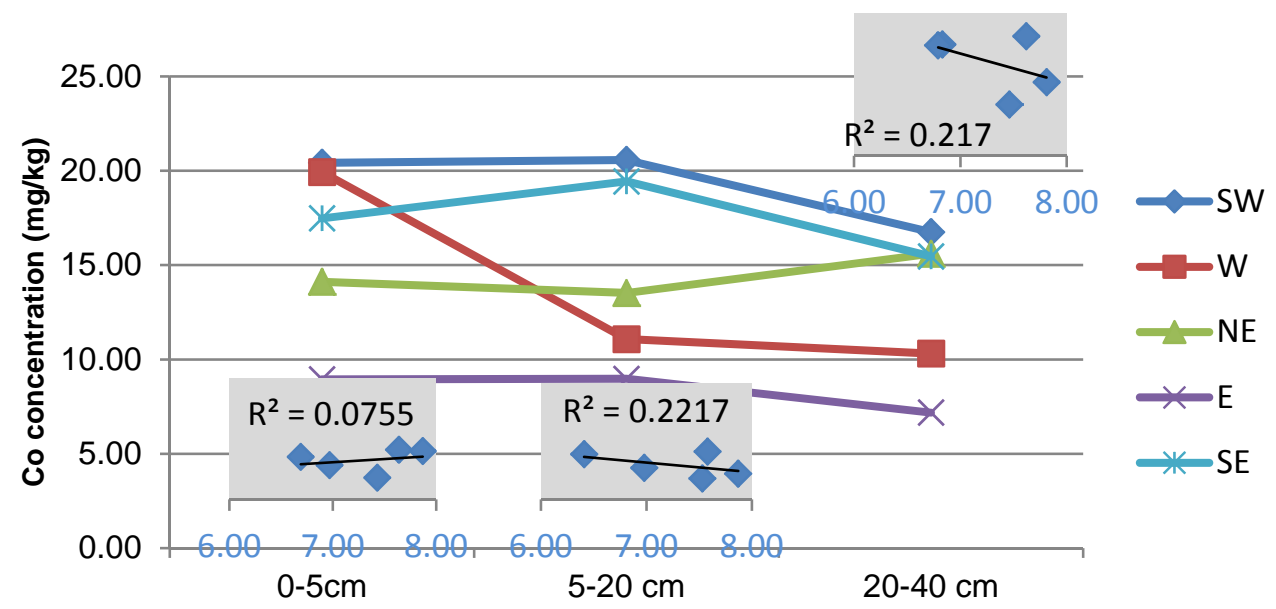

Figure 11. Cobalt vertical distribution in soil and correlation with $\mathrm{pH}$

$\mathrm{pH}$, in the 5-20 cm layer the correlation was strong (>0.6) and in the lower part of the soil profile correlation was moderate.

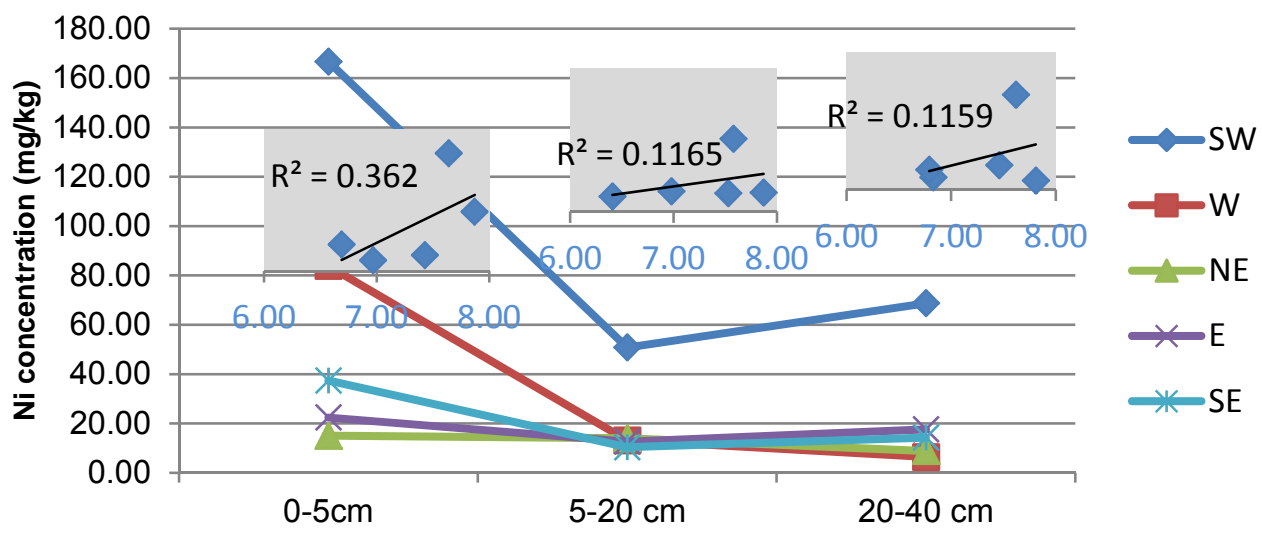

Figure 12. Nickel vertical distribution in soil and correlation with $\mathrm{pH}$

The soils in Zone II showed similar values of $\mathrm{Cr}$ concentration on the entire soil profile, observing only a slight increase in the median layer (Figure 14). In the SW and W directions, $\mathrm{Cr}$ distribution differed on the soil profile. In the surface layer the concentration had high values, but they decreased with the depth. Only in the surface layer the concentration of $\mathrm{Cr}$ in the soil had a strong correlation with $\mathrm{pH}$ of soil $(>0.6)$. 


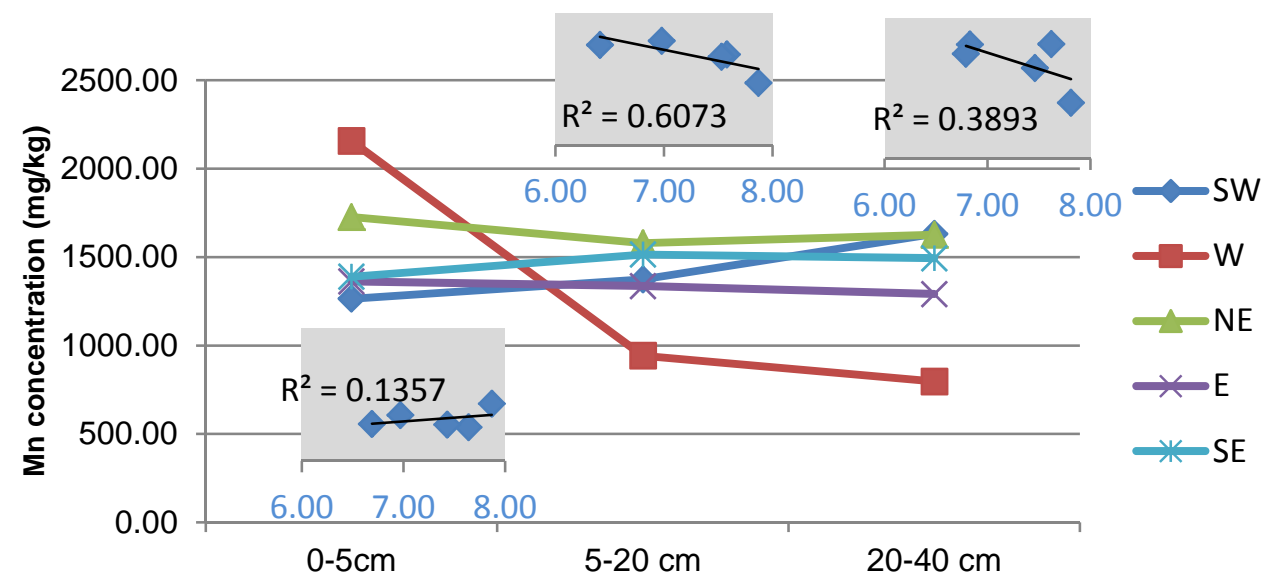

Figure 13. Manganese vertical distribution in soil and correlation with $\mathrm{pH}$

The Mo concentration varied widely in depth of soil profile (Figure 15). In the SW, NE and SE directions the concentrations decreased significantly in the middle of the profile and remain at the same value at the bottom of it. In the $\mathrm{W}$ direction, a higher concentration of Mo (4.94 $\mathrm{mg} / \mathrm{kg}$ ) was found at a depth of 5-20 cm. The best correlation between the Mo concentration in soil and $\mathrm{pH}$ was at depth of $5-20 \mathrm{~cm}$, with values $>0.4$. The upper and lower layers had a lower correlation between Mo concentration and $\mathrm{pH}$.

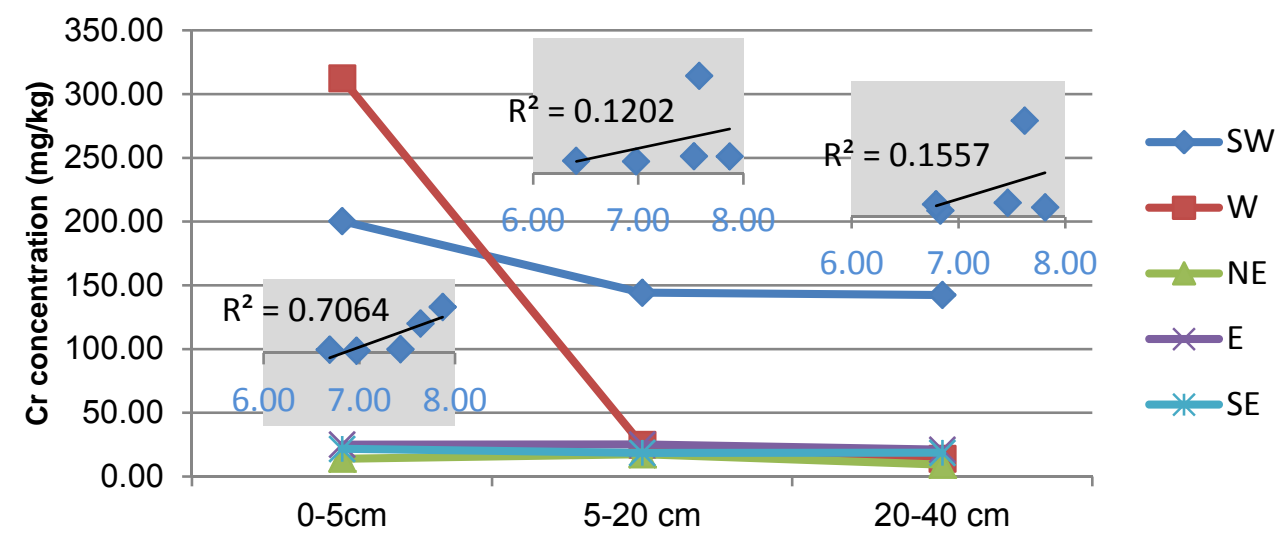

Figure 14. Chromium vertical distribution in soil and correlation with $\mathrm{pH}$ 


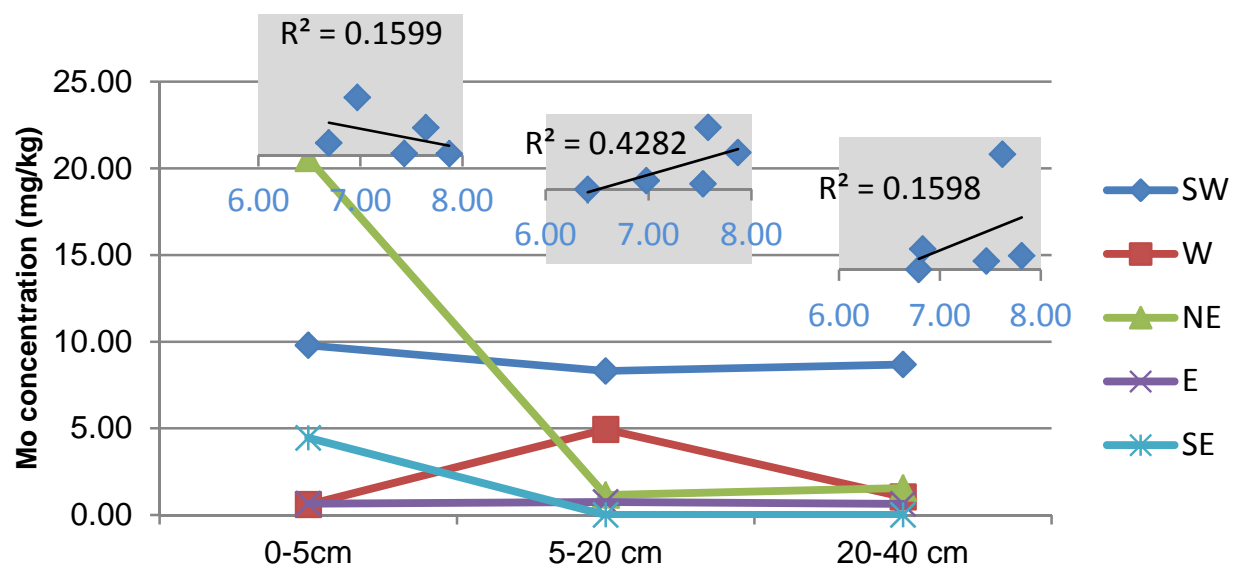

Figure 15. Molybdenum vertical distribution in soil and correlation with $\mathrm{pH}$

The statistical analysis indicated that the heavy metal concentration in soil is negatively correlated with the depth, as the metal concentration decreased with the increasing of depth (Table 5). The correlation was statistically significant at level lower than 5\%. Heavy metal concentration in soil was positively correlated with the $\mathrm{pH}$ of soil, with low to moderate intensity, except the Mn concentration which showed a very low negative concentration.

\begin{tabular}{|c|c|c|c|c|c|c|c|c|c|}
\hline & $\mathrm{Cu}$ & $\mathrm{Zn}$ & Sn & $\mathrm{Pb}$ & Co & $\mathrm{Ni}$ & Mn & $\mathrm{Cr}$ & Mo \\
\hline Depth & $-0.2454^{a}$ & $-0.3469^{a}$ & $-0.5965^{a}$ & $-0.2588^{a}$ & $-0.2907^{a}$ & $-0.3879^{a}$ & $-0.2639^{c}$ & $-0.3277^{a}$ & $-0.3469^{c}$ \\
\hline $\mathrm{pH}$ & $0.3796^{a}$ & $0.4171^{a}$ & $0.1554^{b}$ & $0.5066^{a}$ & $0.5675^{c}$ & $0.3991^{a}$ & $-0.0995^{c}$ & $0.5007^{a}$ & $0.0932^{a}$ \\
\hline
\end{tabular}

Table 5 Pearson coefficient of correlation between heavy metal concentrations in soil and depth and pH of soil

\subsection{Vertical mobility index of heavy metals in soil}

The vertical mobility index (VMI) represents the relative explanation of heavy metal concentration between two underlying layer of soil: between $0-5 \mathrm{~cm}$ and $5-20 \mathrm{~cm}$; between $5-20 \mathrm{~cm}$ and $20-40 \mathrm{~cm}$ (Figure 16). The metal mobility between layers was statistically significant at $95 \%$ confidence level. VMI will indicate a very weak mobility of metal at values lower than $20 \%$, weak mobility of metal at values between 20 and $40 \%$, moderate mobility of metal at values between 40 and $60 \%$, strong mobility at values between 60 and $80 \%$, and very strong mobility at values higher than $80 \%$.

Distribution of $\mathrm{Cu}$ in the soil profile was given by the very strong correlation of the concentration of this element in the three layers of soil profile. High values of vertical mobility index were observed between the concentrations of $\mathrm{Cu}$ in the two underlying layers, which demon- 
strated the very high mobility of $\mathrm{Cu}$ in the soil, mobility influenced also by the $\mathrm{pH}$. Values of correlation between concentrations at different depths indicated weak Zn mobility on the soil profile to depth of $20 \mathrm{~cm}$ and a very strong mobility between 20 and $40 \mathrm{~cm}$.

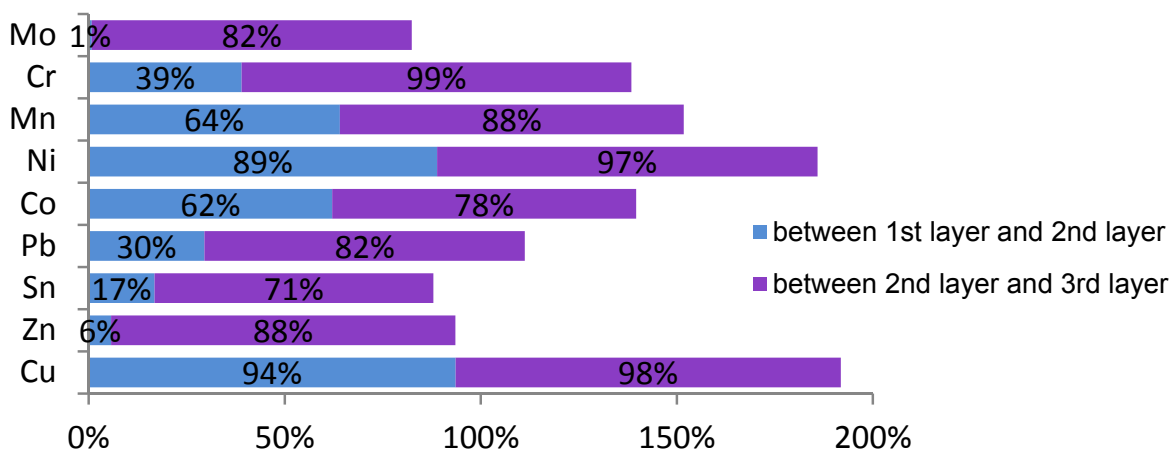

Figure 16. Vertical mobility index (VMI) of heavy metals between the layers of the soil profile, statistically significant at $95 \%$ confidence level

The mobility index of Sn was different depending on the depth. In the surface layer, this metal had a weak mobility; the correlation between the two layers $(0-5 \mathrm{~cm}$ and $5-20 \mathrm{~cm})$ was very low. At greater depths, Sn mobility index was higher, indicated by the strong correlation of the concentrations at depths greater than $20 \mathrm{~cm}$. Correlation of $\mathrm{Pb}$ concentration between layer of $0-5 \mathrm{~cm}$ and the other two layers was very low $(<0.3)$. A strong correlation exists only between 5-20 $\mathrm{cm}$ and $20-40 \mathrm{~cm}$ depth which indicate a very strong mobility of $\mathrm{Pb}$. The correlation between the concentrations of $\mathrm{Co}$ in the soil profile indicated a strong mobility of metal between the surface layer and underlying layers. The correlation between the Ni concentrations of different depths of soil profile is very strong, indicating a very strong mobility of $\mathrm{Ni}$ in soil which increased with depth.

The correlation between the concentrations of $\mathrm{Mn}$ in different depths of the soil profile is very strong, which indicated that a significant increase in the concentration of $\mathrm{Mn}$ in the upper layer will lead to an increase of Mn concentration also in the depth due to very strong mobility of this metal. The correlation between the concentrations of $\mathrm{Cr}$ in different depths of soil profile indicated a weak mobility of $\mathrm{Cr}$ between the surface layer and the middle layer of soil profile and a very strong mobility in the lower part of the soil profile. Correlations between the Mo concentrations were different on the soil profile: very weak in its upper layer and strong in the lower layers of soil profile.

\section{Discussion}

Because of the metallurgical activities carried out in the vicinity of Targoviste, which produced in time significant amounts of particulate matter with a high content of $\mathrm{Pb}, \mathrm{Cr}, \mathrm{Cu}, \mathrm{Mn}, \mathrm{Ni}$ and 
$\mathrm{Zn}$, the quality of agricultural soils is negatively influenced by the concentrations of heavy metals, which represent a risk of toxicity to humans. In order to evaluate the degree of loading of soils with heavy metals, the present study shows: (i) the horizontal distribution of heavy metals, depending on the prevailing direction of the air masses movement (wind rose) and (ii) vertical distribution to highlight the mobility of heavy metals into the soil profile, depending on the depth to which the plant roots can be found [15].

Previous studies have shown Targoviste area as an area of potential risk of heavy metal toxicity, along with other sources of pollution in Romania, as Copşa Mică, Deva and Baia Mare. This study presents the results of the concentration of heavy metals in soils near Targoviste, and are considered the high risk toxic metals such as $\mathrm{Cu}, \mathrm{Zn}, \mathrm{Sn}, \mathrm{Pb}, \mathrm{Co}, \mathrm{Ni}, \mathrm{Mn}, \mathrm{Cr}, \mathrm{Mo}$. The analysis of horizontal distribution of heavy metals (Table 4 ) indicated that the agricultural soil in the vicinity of metallurgical unit were loaded with heavy metals concentrations exceeding several times the normal values and even alert threshold. Some values indicated concentrations of $\mathrm{Cu}$ and Zn even higher than in Copşa Mică [16] and Baia Mare [17].

Soils most affected by heavy metal pollution were those located on SV and V directions against the source of pollution, which are the predominant direction of air masses movement in the studied area. Also the other studied directions are characterized by concentration of heavy metals higher than normal limits, constituting a potential risk in the use of those soils in agriculture.

Analysis of vertical distribution of heavy metals indicated that high levels of heavy metals are caused primarily by industrial activity and less by the concentration of metals in the parent material. The concentration of all metals was higher in surface layer of soil $(0-5 \mathrm{~cm})$ because of deposition of particulate matter [21] and lower in the deeper layers of soil, possibly due to binding of metals to soil organic fractions (in the surface layer) that have slowed the metal mobility on the profile and decreased the transfer of metals to the underlying layers. Statistical analysis of correlations between the metal concentrations in soil and depth of the soil layer showed a negative correlation, which confirmed the hypothesis that the high concentration of heavy metals in soils from the industrial area of Targoviste, comes from a source of pollution and not from the parent material.

The metal mobility from the surface layers to the deeper layers can be explained on the basis of vertical distribution pattern of heavy metal. In order to measure the metal mobility on the profile of soil, a vertical mobility index (VMI) was calculated. This index indicated the extent to which that metal from a top layer of soil was transferred to the deeper layer by leaching and adsorption to soil particles. Depending on the type of soil, the mobility varies, promoting or inhibiting the rate of metal transfer from surface soil to groundwater, where the toxicity hazard is more difficult to control and the remediation actions are trickier. The most mobile heavy metals in investigated soils were $\mathrm{Cu}$ and $\mathrm{Ni}$, with a mobility of $94 \%$ and $89 \%$ respectively, between the two layers from the surface of soil profile and a mobility of $98 \%$ and $97 \%$ respectively, between the two deeper layers. The hazard risk of these two metals to get into the groundwater was expressed by the high values of VMI. Also Mn and Co showed quite high values of VMI, which placed them as potential hazardous metals. Analysis of heavy metal mobility is important because once they reached the groundwater they present a greater risk 
to humans. Long-term exposure to high concentrations of these metals can cause serious illnesses in humans $[4,10,11]$, and the intervention for remediation of soil is urgent, before the heavy metals will reach the groundwater.

\section{Conclusions}

Following chemical analysis by ICP-AES, we found the heavy metal concentration levels above the normal value of an industrial soil, and sometimes even exceeding the alert limit (according to Order 756/1997).

Distribution of heavy metals on soil profile showed that accumulation of metal in the soil decreases with the depth. The concentrations were higher on the surface of the soil profile. This indicates a continuous impact of metallurgical activities on soil by accumulating new quantities of metals.

The concentration of heavy metals in soil was also considered to be in connection with the $\mathrm{pH}$ and chemical composition of soil: the presence or absence of other metallic elements.

The vertical mobility index indicated moderate to strong mobility of majority of studied metals, especially in the lower layer of the soil profile, $20-40 \mathrm{~cm}$.

\section{Acknowledgements}

The research is part of the $\mathrm{PhD}$ thesis "Studies and research concerning the remediation of heavy metal polluted soil by eco-technological procedure", in Romanian, realized by the author in 2011. Is a good opportunity to thank my colleagues Sorin Ciulei for his support in soil assessment and evaluation, Irina Fierascu and Radu Claudiu Fierascu for their support in the sample analyses by ICP-AES. Also I want to thank my thesis coordinator, Prof. Georghe Ionita for guidance in preparing the thesis and to Prof. Dumitru Ion for the financial support for the publication.

\section{Author details}

\section{Carmen Cristina Elekes*}

Address all correspondence to: cristina_elekesh@yahoo.com

“Valahia" University of Târgovişte, Dâmboviţa, Department of Environmental Engineering, Romania 


\section{References}

[1] FOREGS Geochemical Baseline Mapping Programme Geochemical Atlas of Europe, 2005, ISBN 951-690-913-2, http://www.gsf.fi/publ/foregsatlas/.

[2] Kabata-Pendias A. Trace elements in soils and plants, fourth edition. Boca Raton, U.S.A.: CRC Press, Taylor and Francis Group; 2010.

[3] Order no. 756 from $3^{\text {rd }}$ November 1997 for the approval of the Regulation of environmental pollution assessment.

[4] Géczi A, Bódis K. Környezeti monitoring Verespatak-Aabrudbánya vidékén. Kriterion, Cluj Napoca 2003, http://www.rosiamontana.ro/img_upload/ c77c3453789af5de5049783 baaa35f31/Anexa_2_verespatak_kutjel_pdf_RO.pdf.

[5] Sumner ME. Handbook of Soil Science. Boca Raton, Florida: Taylor \& Francis; 2000.

[6] Salmon SU. Geochimical Modelling of Acid Mine Drainage in Mill Tailings, KTH, Land and Water Resources Engineering, Stockholm, Sweden: Doctoral Thesis; 2003, ISBN 91-7283-607-5.

[7] Kabata-Pendias A, Krakowiak A. Useful phytoindicator (dandelion) for trace metal pollution, Proc. $5^{\text {th }}$ Int. Conf. Transport, Fate and Effects of Silver in the Environ., Andren A.W. and Bober T.W., eds., Argentum, Madison, WI 1998, 145.

[8] Schafer SG, Femfert U. Tin - a toxic heavy metal? A review of the literature, Regulatory and Environmental Health 1985; $457-69$.

[9] Kaminski MD, Landsberger S. Heavy metals in urban soils of East St. Louis, IL. Part I: Total concentration of heavy metals in soils, Journal of the Air \& Waste Management Association 2000; 50(9) 1667-1679.

[10] Domingo JL. Cobalt in the Environment and Its Toxicological Implications, Rev Environ Contam Toxicol 1989; 108 105-132.

[11] Agency for Toxic Substances and Disease Registry (ATSDR). Toxicological Profile for Manganese (Update). Draft for Public Comment. U.S. Public Health Service, U.S. Department of Health and Human Services, Atlanta, GA. 1997.

[12] Lenntech, Chemical properties of molibdenum - Health effects of molybdenum - Environmental effects of molybdenum, http://www.lenntech.com/periodic/elements/ mo.htm [accessed 02.12.2013].

[13] Dumitru M, Răuță C, Toti M, Gamenț E, Motelică DM. Impact of emissions loaded with heavy metals on soil land plant, Contaminated soil. Netherlands: Kluwer Academic Publishers; 1995, 607-607.

[14] Lăcătuşu R, Ghelase I. Heavy metal abundance in soil, in Romanian, Mediul înconjurător 1992; III (4) 44-52. 
[15] Răuţă C, Lăcătuşu R, Cârstea S. (1992) Heavy metal pollution of soils in Romania, Mediul înconjurător 1992; III (4) 33-44.

[16] Vrînceanu NO, Motelică DM, Dumitru M, Toti M, Gamenț E, Tănase V. Aspects concerning soil pollution with heavy metals in Copşa Mică area, Proceedings of International Conference "Soil under Global Change", Constanța, România 2002, 357-365.

[17] Lăcătuşu R, Cârstea S, Lungu M, Kovacsovics B, Lazăr R. Soil pollution with cyanides and heavy metals in the Baia Mare area; ecological reconstruction, Soil Science 2002; 36(1) 77-87.

[18] Dumitrescu C et al. Methods and technics of evaluation and neutralization of pollutants, in Romanian, Bucharest; 2002, ISBN 973-652-643-7, 30-110.

[19] Müller G. Soil biology, in Romanian, Bucharest: Ed. Agro Silvică; 1965.

[20] Herms U, Brümmer GW. Einflussgrössen der Schwermetallöslichkeit und -binding in Boden. Z. Pflanzenernaehr, Bodenkd 1984; 147, 400.

[21] Regional Environmental Protection Agency Piteşti, Integrated Environmental Authorization, no. 159/30.10.2007, requested by S.C. Mechel Târgovişte S.A.

[22] MEMDUR: Sustainable resource management system for environmental monitoring and risk assessment in order to prevent negative effects of crisis management - Scientific and Technical Report (RST) no. D11-037/2007.

[23] Teodorescu-Soare E. Pedology, in Romanian, Iaşi: Ed. „Ion Ionescu de la Brad”; 2006.

[24] Costea T, Istudor V, Fierascu RC, Fierascu I, Botez A. Researches upon indigenous herbal products for therapeutic valorification in metabolic diseases Note I. Betulae folium and Rubi idaei folium, sources of micro- and macroelements. Farmacia 2013; 61: 1 .

[25] Elekes CC, Ioniţă Gh, Busuioc G. The bioconversion factor of some green plants growth in the metallurgic industrial area. Annals of Food Science and Technology, Târgovişte 2009; 10(2) 580-585.

[26] Elekes CC, Dumitriu I. The impact of metallurgic activities on the soil quality in Dâmbovita County. Scientific Papers. Agronomy Series, Ed. "Ion Ionescu de la Brad" 2009; 52(1) 345-350.

[27] Ioniţă Gh, Elekes CC. Studies and research concerning the polluted soils decontamination by biosystems. Conference Proceedings of the Academy of Romanian Scientists, Bucharest 2009; 1(1) 201-210. 